\title{
AUNC
}

Zabytkoznawstwo i Konserwatorstwo XLVII

Toruń 2016

DOI: http://dx.doi.org/10.12775/AUNC_ZiK.2016.005

\section{Zagadnienia technologii i techniki malarskiej Gerarda de Lairesse na podstawie traktatu o malarstwie „Het Groot Schilderboek"*}

\author{
JUSTYNA OLSZEWSKA-ŚWIETLIK \\ Zakład Technologii i Technik Malarskich, Wydział Sztuk Pięknych, UMK w Toruniu \\ e-mail: justolsz@umk.pl
}

EWELINA MACIEJCZYK

e-mail: ewelina.maciejczyk.kon@gmail.com

Keywords: Gerard de Lairesse, a treatise on painting, Het Groot Schilderboek, technology and painting technique, Dutch seventeenth century painting, Amsterdam

Słowa kluczowe: Gerard de Lairesse, traktat o malarstwie, Het Groot Schilgerboek, technologia i technika malarska, malarstwo holenderskie XVII wieku, Amsterdam

\begin{abstract}
Issues of the technology and the painting technique of Gerard de Lairesse based on the treatise on the painting "Het Groot Schilderboek"

Treatise Het Groot Schilderboek (“The Great Book on Painting”) of Gerard de Lairesse (1640-1711) belongs to important works which apart from theoretical issues include relevant information concerning painting technique. In the 17th and 18th century theoretical papers on the painting enjoyed great interest in the whole of
\end{abstract}

Prace naukowe i artystyczne związane $\mathrm{z}$ traktatem zostały wykonane w ramach prowadzonych przez autorki badań technologii i techniki malarskiej Gerarda de Lairesse. Ich wyniki zob. m.in. Ewelina Maciejczyk, „Zagadnienia techniki i technologii malarskiej Gerarda de Lairesse, XVIII wiek" (praca magisterska, Uniwersytet Mikołaja Kopernika w Toruniu, 2016). 
Europe. The treatise by de Lairesse was well-known also amongst the artists active in Gdańsk, Toruń, and Elbląg in the Polish-Lithuanian Commonwealth. Up to the 18th century artists in Poland-Lithuania received their professional training within the framework of a guild system. The system of learning required copying of the famous ancient and modern works from prints. In Gdańsk and Torun the works by de Lairesse enjoyed considerable popularity and were often copied. Given the significance of the work of the Dutch artist in Royal Prussia a project was initiated to recreate the painting technique described in his treatise. A copy of a painting by the artist was made fallowing available literature and an in-depth study of the treatise itself. The aim was to recreate in a practical way the technical details of the old workshop practice. The results of the analyses and of technological reconstructions can be used in conservation practice as well as in artistic activity.

\begin{abstract}
Abstrakt
Traktat Het groot schilderboek („Wielka księga malarska”) Gerarda de Lairesse (1640-1711) należy do znaczących dzieł, w których oprócz zagadnień teoretycznych zawarto istotne informacje dotyczące techniki malarskiej. W XVII i XVIII wieku prace teoretyczne o malarstwie cieszyły się dużym zainteresowaniem w całej Europie. Traktat de Lairesse’a znany był na przykład wśród artystów Gdańska, Torunia, Elbląga. Do wieku XVIII artyści polscy zdobywali doświadczenie głównie w ramach systemu cechowego. System nauki wymagał m.in. kopiowania znanych dzieł antycznych i nowożytnych reprodukowanych w postaci sztychów. W środowisku gdańskim i toruńskim dużym powodzeniem cieszyły się reprodukcje dzieł de Lairesse’a, które były często kopiowane. W związku ze znaczeniem pracy holenderskiego artysty w środowisku malarskim ówczesnych Prus Królewskich zajęto się badaniami, które umożliwiły odtworzenie techniki malarskiej opisanej w jego traktacie. Opierając się na dostępnej literaturze i dogłębnych studiach nad traktatem wykonano kopię wybranego obrazu artysty. Praca miała na celu praktyczne poznanie tajników dawnego warsztatu, praktyki. Wyniki analiz i rekonstrukcji technologicznych mogą być wykorzystane w praktyce konserwatorskiej oraz przy wykonywaniu prac artystycznych.
\end{abstract}

Gerard de Lairesse, holenderski malarz, rysownik, grafik i teoretyk sztuki, urodził się 11 września 1640 roku w Liège w Belgii, gdzie spędził lata młodości ${ }^{1}$. W XVII wieku w tym mieście rozwinęła się autonomiczna szkoła malarska - tzw. szkoła leodyjska, reprezentowana m.in. przez G. Douffeta (1594 Liège -1660), B. Flemalle’a (1614 Liège - 1675), J. G. Carliera (1638

Robert Genaille, Encyklopedia malarstwa flamandzkiego i holenderskiego, aktualizacja, uzupełnienie i nowe hasła, tłum. Maciej Monkiewicz, Antoni Ziemba (Warszawa: PWN, 2001), 205. 
Liège -1675$)^{2}$. Pierwsze nauki malarstwa Gerard pobierał zapewne u ojca, Raniera de Lairesse’a, który był malarzem ${ }^{3}$. W swoich wczesnych pracach, takich jak np. Nawrócenie św. Augustyna, pozostawał pod wpływem Bertholeta Flemalle’a, jednego z najwybitniejszych wówczas przedstawicieli szkoły leodyjskiej, i prawdopodobnie u niego pobierał dalsze nauki. Uważa się, że właśnie od Flemalle’a przejął zamiłowanie do sztuki klasycznej ${ }^{4}$ W 1660 roku krótko pracował w Kolonii dla tamtejszego elektora i arcybiskupa, w latach 1650-1688 pełniącego także urząd biskupa Liège. W roku 1664 na skutek konfliktu o podłożu obyczajowym de Lairesse zmuszony był do ucieczki z rodzinnego miasta. Zawarł związek małżeński z Marią Salmą i na pewien czas osiedlił się w Utrechcie. Gdy jego talent malarski dostrzegł holenderski malarz i marszand sztuki Gerriten van Uylenburgh (1625-1697), zawarł z nim umowę i przeniósł się wraz z rodziną do Amsterdamu ${ }^{5}$. Tam wkrótce poznał Rembrandta, skoligaconego z rodziną Uylenburgh: jego pierwsza żona Saskia van Uylenburgh była kuzynką ojca Gerritena - Hendrica (1606-1669), który zajmował się karierą malarza ${ }^{6}$, a po śmierci ojca rodzinny biznes przejął syn. Rembrandt około 1665/1667 roku namalował realistyczny portret młodego (w wieku około dwudziestu czterech lat) Gerarda, dziś przechowywany w Metropolitan Museum of Art w Nowym Jorku. Obraz, obecnie jeden z najbardziej znanych wizerunków de Lairesse'a, ukazuje jego twarz charakterystycznie zmienioną przez wrodzoną chorobę (kiłę) ${ }^{7}$. W roku 1667 de Lairesse otrzymał

2 Genaille, Encyklopedia, 108-109, 128, 79.

3 Genaille, Encyklopedia, 128.

4 Bertholet Flemalle (1614-1675) - barokowy malarz w Liège (Belgia). W 1638 r. odwiedził Rzym, następnie Paryż, gdzie współtworzył malarską dekorację pałacu w Wersalu. W $1647 \mathrm{r}$. wrócił do Liège i wykonał wiele obrazów dla miejscowych kościołów. W 1670 r. wyjechał do Paryża, gdzie Ludwik XIV mianował go profesorem Królewskiej Akademii. Pod koniec życia osiadł w Liège. G. de Lairesse był jednym z jego uczniów. Genaille, Encyklopedia, 128.

5 Bob Haak, The Golden Age. Dutch Painters of the Seventeenth Century (London: Stewart, Tabori \& Chang, 1984), 216-220; Friso Lammerste i Jaap van der Veen, red., Uylenburgh en zoon. Kunst en commercie van Rembrandt tot de Lairesse 1625-1675 (Amsterdam: Waanders; Museum Het Rembrandthuis, 2006).

6 Podobnie jak Rembrandt pochowany w Westerkerk, protestanckim kościele w centrum Amsterdamu, w którym de Lairesse w 1686 r. wykonał dekoracje malarskie organów. http:// www.westerkerk.nl/english; http://mikestravelguide.com/things-to-do-in-amsterdam-visit-westerkerk-and-climb-westertoren/ (dostęp 14 listopada 2015); Frederik Schmidt-Degener, "Rembrandt's Portret van Gerard de Lairesse", Onze Kunst 23 (1913): 117-129 (dostęp 15 marca 2015).

7 Oznaki wrodzonej kiły na portrecie wykonanym przez Rembrandta pierwsza odkryła w $1913 \mathrm{r}$. dr J. H. Hanken. Za: Horton Johnson. "Gerard de Lairesse, Genius Among the Treponemes", Journal of the Royal Society of Medicine 97 (2004) 6: 301-303 i przypis 10, http://www.ncbi. 
obywatelstwo Amsterdamu. Utalentowany i ceniony artysta, otrzymujący liczne zamówienia na obrazy, został uznany za czołowego przedstawiciela nurtu klasycyzującego ${ }^{8}$.

W roku 1690, w wieku czterdziestu dziewięciu lat, Gerard de Lairesse w wyniku postępującej choroby stracił wzrok. Zmusiło go to do porzucenia działalności artystycznej i skupienia się na teorii sztuki. W tym czasie jedynym źródłem dochodów rodziny były wykłady na temat sztuki, jakie wygłaszał. Korzystając z pomocy synów Abrahama (1670-1727) i Jana (1673-1716) ${ }^{9}$, zajął się też tworzeniem traktatów poświęconych teorii sztuk. W 1701 roku został wydany jego podręcznik omawiający zasady rysunku pt. Grondlegginge der teekenkonst („Podstawy rysunku”). Po sześciu latach ukazał się traktat malarski pt. Het Groot Schilderboek („Wielka księga malarska”). Zaledwie kilka lat później, w roku 1711 artysta zmarł w Amsterdamie.

Gerard de Lairesse odniósł duży sukces w dziedzinie malarstwa, a jego traktaty były znane w całej osiemnastowiecznej Europie, wielokrotnie wznawiane i tłumaczone na inne języki. Kontynuatorami jego stylu malarskiego i doktryn artystycznych byli dwaj synowie: Abraham i Jan ${ }^{10}$. Swoje doświadczenie de Lairesse przekazał również uczniom. Teoretyk sztuki i biograf ma-

nlm.nih.gov/pmc/articles/PMC1079501/ (dostęp 17 marca 2015); Frederik Schmidt-Degener, "Le portrait de Gérard de Lairesse par Rembrandt", L'art flamand et hollandaise 19 (1913): 97-108, http://www.ncbi.nlm.nih.gov/pmc/articles/PMC1079501/ (dostęp 15 marca 2015).

8 Zob. Arnold Houbraken, De groote schouburgh der Nederlantsche konstschilders en schilderessen, t. 3 (Amsterdam: B. M. Israel, 1976), 285, http://www.dbnl.org/tekst/houb005groo01_01/ houb005groo01_01_0353.php (dostęp 27 listopada 2014); Fred G. Meijer i Adriaan van der Willigen, A Dictionary of Dutch and Flemish Still-life Painters Working in Oils, 1525-1725 (Leiden: Primavera Press, 2003), 128.

$9 \quad$ Obaj byli malarzami. Abraham poprawił i przetłumaczył tekst, uwzględniając ówczesny zawodowy żargon malarzy; autor wspomina w traktacie, że nie włada jeszcze sprawnie językiem holenderskim. Zob. Gerard de Lairesse, The Great Book on Painting, tłum. Lyckle de Vries, w Lyckle de Vries, How to Create Beauty. De Lairesse on the Theory and Practice of Making Art (Leiden: Primavera Press, 2011; CD-ROM), 18, tam też obszerna literatura (61-64); Alan Roy, Gerard de Lairesse (Paris: Arthena, 1992), 54, 162; Gerard de Lairesse, Groot Schilderboek, Waar in de Schilderkonst in al hoar deelen grondig werd onderweezen, ook door Redeneeringen en Prentverbeeldingen verklaard; Met Voorbeelden uit de beste Konststukken der Oude en Nieuwe Puikschilderen bevestigd: En derzelver Welen Misstand aangeweezen (Amsterdam: David Mortier, 1714-1715), 139. Jan de Lairesse wykonał grafiki, które ojciec wykorzystał do zilustrowania przykładów omawianych w traktacie: de Vries, How to Create Beauty, 18; de Lairesse, Het Groot Schilderboek, prolog: XIII-XV.

10 http://www.geni.com/people/Abraham-de-Lairesse/6000000027978901472 (dostęp 4 marca 2016); https://rkd.nl/en/explore/artists/Lairesse\%2C\%20Johannes\%20de (dostęp 4 marca 2016). 
larzy holenderskich i flamandzkich Arnold Houbraken (1660-1719) w biografii de Lairesse’a jako jego najbardziej znanych uczniów wymienił m.in. Jana van Mierisa (1660-1690), braci Teodora (1654-1718) i Krzysztofa (Szczecin 1659 - Amsterdam 1729) Lubienieckich, Jacoba van der Doesa (Młodszego) (1623-1673), Louisa Fabritiusa Dubourga (1693-1775), Ottomara Elligera (1633-1679), Jana Goeree (1670-1731), Gilliama van der Gouwena (1640-1720), Bonaventurę van Overbeeka (1660-1705), Hansa Hinricha Rundta (1660-1750), Philipa Tidemana (1657-1705), Jana Wandelaara (1690-1759), Zachariasa Webbera (Młodszego) (1644-1696) ${ }^{11}$. Za najzdolniejszego ucznia uznaje się Jana Hoogsaata (1654-1730) ${ }^{12}$. Poświęcony malarstwu traktat de Lairesse’a cieszył się dużym zainteresowaniem wśród artystów w XVIII wieku

11 Houbraken, De groote schouburgh, 329, http://www.dbnl.org/tekst/houb005groo01_01/houb005groo01_01_0434.php (dostęp 14 listopada 2015). Informacje na temat Teodora Lubienieckiego zob. Houbraken, De groote schouburgh, 329. Na temat Krzysztofa Lubienieckiego zob. Genaille, Encyklopedia, 237; Anna Lewicka-Morawska, Słownik malarzy polskich. Od średniowiecza do modernizmu, t. 1 (Warszawa: Arkady, 1998), 107; jego obrazy, np. Mojżesz wydobywający wodę ze skały, Bakałarz, Smakosze (1710-1719) znajdują się w Muzeum Narodowym w Warszawie; http://www.agraart.pl/cgi-bin/autor.cgi?act=1\&qt=1267736675\&nr=161; w 1682 r. przeniósł się do Polski, gdzie w 1729 r. zmarł. Inni uczniowie de Lairesse’a: J. van der Does - zob. Houbraken, De groote schouburgh, 106-108; Michael Bryan, Dictionary of Painters and Engravers, Biographical and Critical, t. 50 A-K (London: George Bell and sons, 1886), 429, https://archive.org/details/cu31924092716962 (dostęp 4 marca 2016); L. F. Dubourg - zob. FOOLOSCAP FINE ART, http://www.old-master-drawing.com/home/product/ view/13/114.html (dostęp 29 lutego 2016); Abraham Jacob van der Aa, Biographisch woordenboek der Nederlanden, t. 7 (Amsterdam: BM Israel, 1969), 371, http://www.dbnl.org/ tekst/aa_001biog05_01/aa_001biog05_01_0817.php (dostęp 29 lutego 2016); O. Elliger zob. Houbraken, De groote schouburgh, 293; van der Aa, Biographisch woordenboek, 252-253, http://www.dbnl.org/tekst/aa_001biog08_01/aa_001biog08_01_0481.php (dostęp 4 marca 2016); J. Goeree - zob. SPHINX FINE ART, http://www.sphinxfineart.com/Goeree-Jan-DesktopDefault.aspx?tabid=45\&tabindex=44\&artistid=41286 (dostęp 29 lutego 2016); G. van der Gouwen - zob. encyklopedia internetowa, RKD NETHERLANDS INSTITUTE FOR HISTORY https://rkd.nl/en/artists/124717 (dostęp 4 marca 2016); B. van Overbeek - zob. Houbraken, De groote schouburgh, 347, http://www.dbnl.org/tekst/houb005groo01_01/houb005groo01_01_0315.php (dostęp 4 marca 2016); H. H. Rundt - zob. Barbara Hammann, Hans Hinrich Rundt, ein deutscher Maler an der Wende vom 17, zum 18 (München: Ludwig Maximilian University, 1974), http://de.dbpedia.org/page/Hans_Hinrich_Rundt (dostęp 4 marca 2016); Ph. Tideman - zob. Houbraken, De groote schouburgh, 367-371, http://www.dbnl.org/ tekst/houb005groo01_01/houb005groo01_01_0448.php (dostęp 4 marca 2016); J. Wandelaar - zob. INVALUABLE, http://www.invaluable.com/artt/wandelaar-jan-0wra25x0gi (dostęp 29 lutego 2016); Z. Webber (Młodszy) - zob. RKD NETHERLANDS INSTITUTE FOR HISTORY, https://rkd.nl/en/explore/artists/Webber\%2C\%20Zacharias\%20\%28II\%29 (dostęp 4 marca 2016).

12 Zob.Houbraken,De groote schouburgh, s. 334, http://www.dbnl.org/tekst/houb005groo01_01/ houb005groo01_01_0435.php (dostęp 4 marca 2016). 
w Holandii, a także wielu innych krajach, również w Polsce; tłumaczono go na inne języki europejskie ${ }^{13}$.

\section{Het Groot Schilderboek („Wielka księga malarska”) Tom 1}

W czasach de Lairesse'a powstawało wiele prac traktujących o malarstwie. Zwykle wychwalano w nich nową sztukę, która rodziła się w północnych Niderlandach. Natomiast księgi de Lairesse’a można odczytać jako obronę nurtu klasycystycznego w holenderskiej sztuce schyłku XVII wieku ${ }^{14}$. Jego dotyczący malarstwa traktat Het groot schilderboek („Wielka księga malarska”) po raz pierwszy ukazał się dopiero w 1707 roku' ${ }^{15}$, przyczyną opóźnienia

13 Traktat de Lairesse’a był wielokrotnie wznawiany i tłumaczony na inne języki: angielski, niemiecki, francuski. Zob. np. The Art of Painting, in All Its Branches, tłum. John Frederick Fritsch (London: E. Orme, 1738). Do istotnych współczesnych opracowań należy opatrzony obszernym komentarzem przekład na j. angielski dokonany przez de Vriesa, How to Create Beauty, 1-36; z tego tłumaczenia korzystano w trakcie pracy nad niniejszym artykułem. Zob. też Houbraken, De groote schouburgh; Jan Białostocki, Teoretycy, historiografowie i artyści o sztuce. 1600-1700 (Warszawa: PWN, 1994); Jan Białostocki, Studia i rozprawy z dziejów sztuki i myśli o sztuce (Warszawa: PWN, 1959); Lyckle de Vries, Gerard de Lairesse, an Artist Between Stage and Studio (Amsterdam: Amsterdam University Press, 1998); de Vries, How to Create Beauty; Degener, "Rembrandt’s Portret”, 117-129; Roy, Gerard de Lairesse; Gerard de Lairesse, Groot Schilderboek (Amsterdam: Hendrick Desbordes, 1712), http://www.dbnl. org/tekst/lair001groo01_01/index.php (dostęp 26 września 2014); Arno Dolders, "Some Remarks on Lairesse's Groot Schilderboek", Simiolus. Netherlands Quarterly for the History of Art 15 (1985) 3/4: 197-220, http://www.jstor.org/discover/10.2307/3780693?sid=21105713 432483\&uid=387572221 \&uid=60\&uid=70\&uid=3\&uid=2 \&uid=387572231 \&uid=2134 (dostęp 26 września 2014); Johnson, “Gerard de Lairesse”, 301-303, http://www.ncbi.nlm.nih. gov/pmc/articles/PMC1079501/art (dostęp 28 października 2014); Claus Kemmer, "In Search of Classical Form: Gerard de Lairesse's 'Groot Schilderboek' and Seventeenth-Century Dutch Genre Painting”, Simiolus. Netherlands Quarterly for the History of Art 26 (1988) 1/2: 87-115, http://www.jstor.org/stable/3780872 (dostęp 28 października 2014); Derk Persant Snoep, “Gerard de Lairesse als plafond- en kamerschilder”, Bulletin van het Rijksmuseum 18 (1970): 159-217. http://www.jstor.org/discover/10.2307/40381589?sid=21105671720833\& uid=2134\&uid=70\&uid=2\&uid=387572221 \&uid=3\&uid=387572231 \&uid=60 (dostęp 3 lutego 2014); Portret ponad wszystko. Jacob Wessel i jego wiek. Sztuka Gdańska XVIII wieku, red. Anna Mosingiewicz i Dariusz Kaczor (Gdańsk: Muzeum Narodowe, 2005); Anna Mosingiewicz i Emanuel Okoń, „O obrazach, skrzynce cechowej i ‘sztukach towarzyskich'. Uwagi o kształceniu artystycznym w Toruniu i Gdańsku na marginesie działalności Christiana Ernsta Ulricha, osiemnastowiecznego malarza w Toruniu", Zapiski Historyczne 75 (2010) 1: 47-48, przypis 84 .

14 Haak, Golden Age, 61-62; de Vries, Gerard de Lairesse, 71.

15 Gerard de Lairesse, Het Groot Schilderboek. Eerste deel (Amsterdam: Willem de Coup, 1707). http://www.europeana.eu/portal/en/record/9200143/BibliographicResource_2000069511050. html (dostęp 25 marca 2017) 
były problemy z przygotowaniem ilustracji ${ }^{16}$. Wspomniany już malarz i pisarz z Dordrechtu, a przede wszystkim biograf artystów holenderskiego Złotego Wieku Arnold Houbraken wspomniał o Konstgenootschap (Stowarzyszenie Sztuki) jako pierwszym wydawcy ${ }^{17}$.

Het Groot Schilderboek („Wielka księga malarska”) zajmuje się kilkoma konkretnymi problemami, opracowanymi bardzo szczegółowo. Tekst początkowo nie zachęca do dalszej lektury, ponieważ de Lairesse stara się omówić każde zaproponowane przez siebie rozwiązanie we wszystkich możliwych aspektach. Cały traktat w dwóch tomach (taki kształt zachowano w późniejszych wydaniach), liczących po około czterystu stron każdy, obejmuje trzynaście ksiąg podzielonych na rozdziały. Tom I rozpoczyna się prologiem i składa się z sześciu ksiąg, z których pierwsze pięć omawia podstawowe zagadnienia dotyczące techniki malarstwa. Księga I, licząca dwanaście rozdziałów, skupia się na szkicowaniu. Księga II, o dwudziestu dwóch rozdziałach, jest poświęcona kompozycji. Księga III, mająca pięć rozdziałów, wyjaśnia różnicę pomiędzy malarstwem klasycznym a współczesnym. Księga IV w swoich dziewięciu rozdziałach mówi o kolorach. Księga $V$ na stronach dwudziestu pięciu rozdziałów szczegółowo prezentuje zagadnienia światła w obrazie. Kończąca tom I księga VI w siedemnastu rozdziałach rozważa pejzaż jako temat malarski.

Celem niniejszego artykułu jest poznanie zasad warsztatu malarskiego w ujęciu Gerarda de Lairesse'a oraz sprawdzenie ich w praktyce. W związku $\mathrm{z}$ tym skupiono się na pierwszym tomie traktatu, zawiera on bowiem zalecenia artysty dotyczące rodzaju materiałów oraz sposobu modelunku malarskiego. Analizując tekst zwrócono uwagę na elementy potrzebne do wykonania rekonstrukcji malarskiej.

W księdze I („Szkicowanie, drugi odcień, piękno i ruch”) znajdujemy podstawowe informacje na temat szkicowania i przygotowania się do właściwego opracowania monochromatycznego podmalowania (tzw. martwego ubarwienia - „doodverwen” ${ }^{18}$ ) oraz uzyskania kolorów karnacyjnych dla drugiej warstwy malarskiej i ostatniego opracowania najwyższych świateł i cieni.

16 De Lairesse, Groot Schilderboek, ix-xv.

17 Houbraken, De groote schouburgh, 129: „door het Komtgenootschap tot twee Boeken geschikt” („złożony z dwóch woluminów przez Stowarzyszenie Sztuki“); de Vries, Gerard de Lairesse, 100; Białostocki, Teoretycy, 140-147, 255-263.

18 De Lairesse, Groot Schilderboek, 13. 
Księga II („O porządku albo kompozycji”) wprowadza w zagadnienia związane głównie z kompozycją. Szczególną rolę odgrywają w niej postacie ${ }^{19}$, ukazane w różnorodnych pozycjach oraz liczbie i grupach dla uwydatnienia sensu przedstawianego tematu ${ }^{20}$. De Lairesse instruuje, jak przedstawić różnice płci, a także wieku malowanych postaci; jak oddać ich ruchy dla wyrażenia emocji; jak użyć tej wiedzy do utworzenia personifikacji w kompozycji ${ }^{21}$. Wszystkie rozdziały są obficie opatrzone pomocnymi przykładami.

Rdzeniem księgi II jest rozdział piętnasty, który przedstawia główny temat traktatu: „tafereel”22. Termin ten oznacza figuralną kompozycję, zdefiniowaną przez de Lairesse’a jako pokaz albo obraz czegoś, czyli zdarzenie; sugeruje więc działanie i upływ czasu. Słowo „tafereel” zasadniczo wyraża relacje. Czas jako aspekt figuralnych kompozycji jest ogólnie omówiony w rozdziale dwunastym ${ }^{23}$. Szczególne miejsce zajmuje w nim cykl obrazów ilustrujących kolejne sceny tej samej historii i towarzyszący im upływ czasu' ${ }^{24}$. „Taferelen” jako rodzaj kompozycji dzieli się na cztery grupy: prezentuje zdarzenie oparte na faktach albo fikcji oraz mające elementy zaczerpnięte z alegorii lub ich pozbawione (rozdział piętnasty). De Lairesse w żaden sposób nie ogranicza wyboru tematu; jedynie przedstawia tematy o najwyższym według niego znaczeniu. Podaje wiele argumentów i przykładów dla uzasadnienia swojej opinii; zaleca również, by podążać za tymi prostymi radami. Pouczające sceny oparte na wydarzeniach z historii biblijnych lokuje niżej w hierarchii tematów od podobnych scen ukazujących moralny przykład. Sposób wyboru odpowiedniego tematu omawia w rozdziałach: drugim, dziesiątym, szesnastym i dwudziestym pierwszym ${ }^{25}$. Opisuje też postawę, jaką zaobserwował wśród holenderskich malarzy: zaczęli oni kształcić się w prezentacji wybranych przez siebie tematów ${ }^{26}$.

Treść księgi III („O rzeczach antycznych i współczesnych”) najpełniej wyraża temat przedstawiony w rozdziale pierwszym: „O różnicy pomiędzy antycznym a współczesnym malarstwem” - to znaczy różnicy stylu. Wybór malarskiego stylu zależał od kategorii tematu. Klasyczny styl występował

9 De Lairesse, Groot Schilderboek, 43.

20 De Lairesse, Groot Schilderboek, 53.

21 De Lairesse, Groot Schilderboek, 59, 65, 97, 93, 149.

22 De Lairesse, Groot Schilderboek, 115-122; 97.

23 De Lairesse, Groot Schilderboek, 97.

24 De Lairesse, Groot Schilderboek, 139; 159.

25 De Lairesse, Groot Schilderboek, 45, 86, 122, 149.

26 De Lairesse, Groot Schilderboek, 106. 
zawsze w tematach malarskich wyżej usytuowanych w hierarchii. Najwyżej lokował się obraz narracyjny w swoich trzech podkategoriach: wysokiej, środkowej i niskiej. Klasyczny styl był odpowiedni dla mitologicznych i biblijnych historii, natomiast styl współczesny w scenach rodzajowych z codziennego życia. De Lairesse namawiał malarzy do stosowania klasycznego stylu, gloryfikując go i niejednokrotnie przedstawiając pozytywne aspekty takiego wyboru w odniesieniu do szerokiego wachlarza dostępnych tematów. Według de Lairesse'a idealny artysta wybiera do swego dzieła ważny temat należący do kategorii, którą ogólnie określa się jako „historie” (obrazy narracyjne) ${ }^{27}$. Jego zdaniem malarz musi być wszechstronny, aby sprostać wszystkim możliwym zadaniom, jakie przed nim staną. Inspiracje dla wszystkich pozostałych tematów malarskich zalecał czerpać właśnie z obrazów narracyjnych.

De Lairesse zalecał, aby pozbyć się osobistego stylu malarskiego bądź indywidualnych cech, ponieważ ograniczały one możliwości iluzji malowanego obrazu. W jego rozumieniu maniera, czyli styl malarski był odejściem od absolutnego ideału malarskiego. „Malarz nie powinien oszukiwać przez taki albo inny styl, ale właśnie przestrzegać natury, jeśli chce oddać sprawiedliwość sztuce” ${ }^{28}$. Krytykował holenderski realizm oraz tworzenie zbyt surowych form klasycznych. Według niego artyści należący do tego nurtu w swoich pracach nie podążali za naturą, ale kopiowali rzeczywistość niewolniczo albo, co gorsza, odbiegali od rzeczywistości, gdy odwoływali się do własnej wyobraźni; nie szukali piękna, ale stworzonej brzydoty, sprzeciwiając się tym samym zasadom prawdopodobieństwa i przyzwoitości; nie przyczynili się do postępu sztuki odkąd ich praca opierała się na pamięci; nie studiowali sztuki; nie podążali za arcymistrzami Włoch i rzeźbami starożytności, ale pozostali przy sposobie, w którym zostali wyszkoleni przez swoich mistrzów. W rezultacie ich prace wyglądają jak obrazy wykonane w osobistym stylu, a nie jak nieskazitelne lustra idealnego, bezosobowego świata; tym samym nie udało im się stworzyć iluzji.

Księga IV („O kolorach”) w całości jest poświęcona zagadnieniom związanym z warstwą barwną. Omawia główne i rozbite kolory, a także zależności, jakie między nimi występują. Szczególne miejsce zajmuje przedstawienie racjonalnych praw, które powinny decydować o wyborze odpowiednich kolorów. Opierając się głównie na własnym doświadczeniu, de Lairesse stara się

${ }^{27}$ Malarzem „historii”, czyli scen przedstawiających tematy narracyjne, był też de Lairesse. 
wyjaśnić prawa malarstwa, posługując się wieloma przykładami. „Aspekt kolorystyczny traktuję wręcz osobowo, mówiąc o nim jako o figurze - odgrywa on bardzo istotną rolę w całej przestrzeni i kompozycji. W zasadzie jest tym, co określa przedmioty i sytuacje także w stosunku do pory dnia i roku oraz nadaje otoczeniu odpowiednie emocje i buduje odpowiednią narrację"29. Dla autora traktatu wybór kolorów był racjonalnym procesem, na który wpływa wiele czynników. Kolor ma przyciągać uwagę widza, będąc jednym z ważniejszych elementów obrazu spajać całość kompozycji oraz kierować wzrok patrzącego na najważniejsze postaci w przedstawianej scenie. „Trzeba wiedzieć, że moc i blask obrazu zawierają się w jego kolorach, nie w szorstkości jego powierzchni” ${ }^{30}$.

W księdze V („O światłach i cieniach”) znajdziemy informacje o świetle i cieniu oparte przede wszystkim na doświadczeniach autora, a także jego umiejętności wnikliwej obserwacji natury. W dużej mierze podane są tu praktyczne rady. Głównym tematem tej księgi jest perspektywa powietrzna. Słowo perspektywa niemal zawsze pojmuje się w znaczeniu przestrzennej skuteczności światła i koloru, a nie matematycznej budowy. Perspektywa jest spowodowana przez wilgoć powietrza i opisana przez przygasanie kolorów oraz zanik światła i ciemność w dali. De Lairesse uznaje perspektywę powietrzną za jedynie dopuszczalny sposób sugerowania przestrzeni w obrazie ${ }^{31}$. W księdze V omawia perspektywę wynikającą z efektu zastosowania słabych bądź silnych kolorów. Jego zdaniem należy delikatnie obchodzić się z czystymi, jasnymi barwami, ponieważ one sprawiają, że przedmioty pojawiają się bliżej nas, czyli wydobywają przedmioty na pierwszy plan. Jednak wielu malarzy stosuje czyste barwy rutynowo, nie stosując się do zasad perspektywy. De Lairesse potępia takie postępowanie, ponieważ sztuka musi podążać za naturą, jeśli chce trzymać się zasad prawdopodobieństwa i prawdy ${ }^{32}$. Doskonałe naśladowanie rzeczywistości oznacza, że każdy obraz jest albo powinien być przedstawiony w typie trompe l'oeil, a to sugeruje, że dobry obraz powinien przedstawiać obiekty w naturalnej wielkości. Iluzjonizm w niewielkich

29 De Lairesse, Groot Schilderboek, 227.

30 De Lairesse, Groot Schilderboek, 12.

31 De Lairesse, Groot Schilderboek, 315-319.

32 De Lairesse, Groot Schilderboek, 327. 
obrazach jest dopuszczalny jedynie gdy są na nim ukazane przedmioty w dalekiej perspektywie ${ }^{33}$.

W tomie II, na który składa się siedem ksiąg, opisano m.in. mniej ważne tematy malarskie oraz zagadnienia uzupełniające pierwsze księgi tomu I ${ }^{34}$. Rozpoczyna go księga VII - o portretowaniu, podzielona na osiem rozdziałów. Księga VIII traktuje o architekturze i liczy czternaście rozdziałów. Księga IX, o malowaniu sufitów lub plafonów, składa się z dziewiętnastu rozdziałów. Księga X, poświęcona rzeźbiarstwu, ma dziesięć rozdziałów. Księga XI w ośmiu rozdziałach omawia martwą naturę. Księga XII, której tematem są kwiaty, obejmuje sześć rozdziałów. Księga XIII w dziewięciu rozdziałach analizuje zagadnienia rytownictwa.

Różnorodne niezgodności w tekście, podobnie jak nakładanie się podobnych zagadnień, mogą być skutkiem tego, że jego fragmenty powstawały na długo przed podjęciem przez de Lairesse’a decyzji o wydaniu traktatu. Dopiero później zebrał je, poprawił i uzupełnił. Na koniec całość sprawdził i przepisał jego syn.

\section{Technologia i technika malarska według Gerarda de Lairesse}

Na podstawie informacji zawartych w traktacie o malarstwie Het Groot Schilderboek opracowano wybrane aspekty technologii i techniki malarskiej de Lairesse'a, tj. metodę opracowywania poszczególnych partii obrazu oraz palety barw wykorzystywanej przez malarza. Wyniki analiz przedstawiono poniżej w kolejności zgodnej z budową obrazu: od podobrazia do warstw malarskich.

Podobrazie. Wiadomo, że de Lairesse stosował jako podobrazie lniane płótno napięte na drewniane ramy oraz drewniane panele, często o różnorodnych kształtach. Dbał o odpowiednie przygotowanie podobrazia. Wybierał płótna gęsto tkane, o równym splocie i bez żadnej skazy, które przeklejał klejem glutynowym, a następnie pokrywał zaprawą.

Zaprawa. Prawdopodobnie stosował zaprawę kredowo-klejową. Nakładał ją w dwóch warstwach (il. 1a) ${ }^{35}$, a następnie odpowiednio szlifował, aby

33 Malarstwo iluzjonistyczne jest techniką tworzenia realistycznych obrazów ze złudzeniem optycznym, że przedstawione obiekty istnieją w trzech wymiarach.

34 Znalazła w nim miejsce architektura (zob. księga VIII), która stanowiła ważny element pracy de Lairesse'a.

35 W wyniku badania techniki malarskiej obrazu Diana and her companions („Diana i jej towarzysze") Gerarda de Lairesse (datowany na lata 1676-1682; 600 x 800 cm; Rijksmuseum Amsterdam, inv. SK-A-1233) stwierdzono m.in., że malarz użył brązowej zaprawy składa- 
usunąć nierówności powierzchni. Zaprawa była barwiona, w kolorze brązu. Nie bez powodu wybierał taką barwę - ułatwiała ona pracę nad późniejszymi partiami obrazu.

W traktacie de Lairesse’a nie ma szczegółowych informacji na temat przygotowania podobrazia, płótna lub panelu. Zadanie to zostawił on artyście, który odpowiednie umiejętności powinien nabyć wcześniej. W traktacie natomiast skupił się na zagadnieniach związanych z rysunkiem, a w szczególności z opracowywaniem warstwy malarskiej.

Rysunek. W pierwszym etapie wykonywał bardzo szczegółowy rysunek na papierze pokrytym niebieskim kolorem. Jeśli kompozycja była niespójna w jakichś częściach, dopracowywał ją w całości bądź w osobnych jej partiach. Stosował uproszczenia w postaci kolażu, wycinając postaci i układając je na płótnie w poszukiwaniu odpowiednio dobrego ułożenia kompozycji. Dopiero gdy był zadowolony z zestawienia figur tworzył kolejny szkic i w dopracowanej już formie przenosił go na obraz za pomocą węgla. Prawdopodobnie utrwalał go farbą wodną, a całość pokrywał izolacją w postaci cienkiej warstwy werniksu z naturalnej żywicy (il. 1a). Na etapie szkicowania rozplanowywał kolorystykę obrazu, przypisując konkretne pigmenty do danego przedmiotu/postaci. Dbał o dobre zestawienie barw obok siebie, osobno i w całości kompozycji, opierając się na naturalnych zjawiskach. Następnie, według przygotowawczego szkicu, przygotowywał pigmenty („schakeeren”36) do pracy.

Spoiwo. Dla pierwszej warstwy mieszał pigmenty z olejkiem terpentynowym ${ }^{37}$. W następnych barwnych warstwach, nakładanych półkryjąco i laserunkowo, mieszał pigmenty z wcześniej przygotowanym spoiwem olejno-żywicznym (werniks żywiczny rozcieńczany olejkiem terpentynowym) ${ }^{38}$. Spoiwo to składa się z oleju schnącego (lnianego), żywicy naturalnej, olejku

jącej się z dwóch warstw (niestety nie została przeprowadzona szczegółowa analiza rodzaju zastosowanych materiałów i spoiw). Zob. Elsemieke van Rietschoten et al., "Painting by the Rules of Art; the 'Groot Schilderboeck' Compared to the Painting Technique of Jan Lievens and Gerard de Lairesse”, referat na International Symposium on Painting Techniques, Rijksmuseum, Amsterdam, 18-20 września 2013. Analiza wizualna innych obrazów de Lairesse’a wskazuje, że artysta zwykle stosował dwuwarstwową brązową zaprawę (widać to gołym okiem) i wykorzystywał jej barwę w dalszych etapach pracy.

36 Przygotowanie różnych kolorów: de Lairesse, Groot Schilderboek, 96, 45, 205, 211, 220, 229, 402.

37 „Terpentynolie” (olejek terpentynowy): de Lairesse, Groot Schilderboek, 331.

38 „Dunne vernis” (rzadki werniks): de Lairesse, Groot Schilderboek, 14. 
terpentynowego oraz terpentyny weneckiej ${ }^{39}$. Dzięki zastosowaniu tego spoiwa de Lairesse osiągał równomierny i szybki czas wysychania powłoki, bez spękań. Malowidło charakteryzowało się dobrą trwałością i wytrzymałością, przede wszystkim przejrzystością, połyskiem i głębią kolorów. Wymuszało to jednak stosowanie laserunkowych powłok. W końcowym efekcie malarz uzyskiwał powierzchnię dość chudą i mniej odporną na olejki lotne.

Warstwa malarska. De Lairesse rozróżniał kilka etapów pracy: podmalowanie („doodverwen”), nakładanie farby („aanleggen”) i malowanie („opschilderen”) oraz opracowywanie najwyższych świateł i cieni („retoqueren").

Podmalowanie („doodverwen”) ${ }^{40}$. De Lairesse konstruował obraz pracą od dalszego planu ${ }^{41}$. Przez cały czas stosował metodyczny sposób malowania obrazu, budując go w określonych etapach. Używał pełnych tonów oraz półtonów koloru, po czym opracowywał dokładniej cienie i najwyższe światła. Pigmenty nakładał na już wyschnięte lub też na jeszcze mokre warstwy („wet in wet”). Wykorzystywał pewne triki, które ułatwiały mu pracę, takie jak np. pasek ze skalą tonalną barwy („lader $1{ }^{\prime 42}$ ). Po przeniesieniu szkicu kompozycji na płótno opracowywał go wstępnie w pierwszej fazie w modelunku światłocieniowym - monochromatycznym (tzw. martwe ubarwienie - „doodverwen”), o barwie czerwono-brązowej (il. 1b, c). Do opracowania stosował pigmenty takie jak biel ołowiowa, ochry brązowe („bruyn-rood”) oraz odrobinę cynobru. Następnie budował delikatny modelunek, niezbyt kontrastowy światłocieniowo. Jako spoiwo stosował do tej warstwy olejek terpentynowy. Podmalowanie wykonywał sposobem kryjącym, z wykorzystaniem koloru zaprawy, tak, aby mógł stanowić jeden z tonów podmalowania monochromatycznego. Nakładał taką mieszaninę na podłoże malarskie miękkim pędzlem

39 Dodatek olejku terpentynowego powoduje żółknięcie, natomiast dodanie oleju lnianego minimalizuje kruchość żywicy; za: Władysław Ślesiński, Techniki malarskie - spoiwa organiczne (Warszawa: Arkady, 1984), 160-161.

40 Położenie pierwszej warstwy malarskiej (monochromatycznej); „martwe ubarwienie”: de Lairesse, Groot Schilderboek, 12, 13, 38, 39, 329, 331.

${ }^{41}$ Artysta zalecał pracę z tylnego planu, szczególnie gdy w kompozycji dominował krajobraz, ponieważ cienie przedmiotów musiały być związane z jasnością lub szarością nieba. Zdaniem de Lairesse’a malarz powinien zaczynać od tła i wychodzić do przodu - taki sposób pomoże mu zharmonizować cienie i światła w kompozycji. De Lairesse, Groot Schilderboek, 12.

42 Drabina - inaczej skala szarości, pasek papieru pokazujący, jak moduły przedstawiają się w matematycznej perspektywie. De Lairesse, Groot Schilderboek, 261-262, 314. 
do płótna albo panelu. Przykładał do tej warstwy największą wagę, ponieważ gdy była ona wykonana dobrze, artysta mógł kończyć obraz bez poprawek.

Nakładanie farby („aanleggen”) i malowanie („opschilderen”) ${ }^{43}$. Właściwą, drugą warstwę barwną, zbudowaną z konkretnych mieszanin pigmentów, de Lairesse nakładał już półkryjąco i laserunkowo, wykorzystując spoiwo olejno-żywiczne - farbę nakładał cienko z werniksem („dun”44), bardziej transparentnie i przejrzyście („schommelen”45) (il. 1d). Efekt laserunkowej, przezroczystej powłoki osiągał przez stosowanie słabo kryjących pigmentów (np. naturalna ultramaryna, siena palona, ziemia zielona itp.), mocno rozrzedzonych przy użyciu medium żywiczno-olejnego. Na tym etapie najważniejszym zadaniem malarza było nadanie głównym wydarzeniom przedstawionym na obrazie odpowiednich kolorów, z zapewnieniem ich harmonii („harmonie”46). Przewodnie barwy (,geplumeerd”47) nadawał scenie już w pierwszej fazie uzbrajania kolorystycznego. Wybierał odpowiednio główne kolory („hoofd-koleur”48) oraz kolory rozbite albo zmieszane, stonowane („gerbo(o)ken koleur”49) przez złamanie barwy o ton w dół („verbreeken 1 ”50) albo zmieszanie jej z inną barwą („verbreeken $\left.2{ }^{51}\right)^{52}$. Malarz pracował w niezbyt grubej war-

43 Nałożenie równych płaszczyzn farby bez opracowania detali: de Lairesse, Groot Schilderboek, $9,11,13,15,16,18,38-40,268,331,332$; położenie drugiej warstwy farby, na górze („doodvrewen”): de Lairesse, Groot Schilderboek, 8, 13, 36, 38-40, 50, 257, 277, 320, 330, 332.

44 „Cienko”; należy nakładać cienką warstwę farby z werniksem, transparentnie: de Lairesse, Groot Schilderboek, 14, 39, 257, 314, 331.

45 Laserunek, rozprowadzanie farby cienko, przejrzyście: de Lairesse, Groot Schilderboek, 12, $36,39,361$.

46 Harmonia kolorów jako kombinacji w obrazie: de Lairesse, Groot Schilderboek, 45, 109, 116, 205, 208, 225, 227, 228, 240, 359, 367, 380, 402, 403.

47 Nadanie przewodnich barw na pierwszej warstwie malarskiej (uzbrajanie): de Lairesse, Groot Schilderboek, 329.

48 Główny kolor: de Lairesse, Groot Schilderboek, 206, 208, 212, 214, 221, 226, 239.

49 Stonowany kolor: de Lairesse, Groot Schilderboek, 109, 206, 208, 219, 220, 223, 226, 227, 230, 252,360 .

50 Złamanie barw: de Lairesse, Groot Schilderboek, 41, 220, 224, 241, 242, 278, 310, 313, 314, 323, 325, 360, 387.

51 Rozbite kolory: de Lairesse, Groot Schilderboek, 249, 263, 268, 269, 272, 310, 351, 371, 372, 386, 388.

52 Świecące i czyste kolory tracą siłę, kiedy zostaną połączone z bielą w celu ich tonalnego rozjaśnienia. To tłumaczy, dlaczego terminy „bruyn” („ciemny”) i „schoon” („czysty”) w niektórych uwagach w Schilderboek się pokrywają. Siła koloru jest tym, co decyduje o jego cieple i intensywności. Barwy takie jak czerwień i żółcień zaliczają się do obu kategorii wyraźnych kolorów, przeciwnych lekkim i słabym. Ich siła zależy również od intensywności cienia. W tej sytuacji de Lairesse, dla ułatwienia, podobnie jak wtedy, gdy szukał odpowiedniej skali tonalnej danego koloru, przy wyborze właściwej siły głębi w relacji do źródła światła posługiwał się paskiem ze skalą cieni („lader 2”). De Lairesse, Groot Schilderboek, 314. 
stwie. Pigmenty nakładał równomiernie, czyli w równych polach malarskich („grond 2”53; „grond 3”54) bez opracowywania szczegółów (,aanleggen” ${ }^{55}$ ), pamiętając o właściwym sposobie posługiwania się pędzlem oraz odpowiedniej gamie kolorystycznej, którą wcześniej opracował we wstępnych szkicach. Linię odseparowanych od siebie pól kolorystycznych wygładzał na powierzchni, jeszcze podczas wysychania farby, miękko śmiałymi ruchami suchego pędzla („(ver)dryen” ${ }^{56}$ ), uzyskując efekt stopienia, scalenia wszystkich kolorów. Gdy już wszystkie kolory miał opracowane, w tej warstwie nakładał laserunek na partie karnacji. Wykorzystywał do tego celu czystą ultramarynę ze spoiwem olejno-żywicznym. Ten sposób miał nadać karnacji naturalny wygląd.

Opracowywanie najwyższych świateł i cieni (,retoqueren”) ${ }^{57}$. W ostatnim etapie de Lairesse opracowywał najgłębsze cienie („diepen”58) i najwyższe światła („hoogsel” ${ }^{59}$ ), korzystając z gamy kolorów, których użył do pierwszej warstwy malarskiej. Budował tony walorowo mieszając kolor lokalny $\mathrm{z}$ bielą lub czernią i uzyskując w ten sposób konkretny odcień szarości. Stosował tzw. paski tonalne, które ułatwiały mu pracę. Kolejne partie opracowywał bardzo szczegółowo i wychodził do świateł w górę (il. 1e). Światło nadawał na sam koniec pracy, ostatecznie uplastyczniając formy. Modelunek światłocieniowy kształtował delikatnie, nie dopuszczając do zbyt dużych kontrastów. Ważne na tym etapie było tworzenie plastyczności formy przez odpowiednie nałożenie cieni i półcieni („mezzezint”). Do tak przygotowanej powierzchni obrazu wnosił niewielkie poprawki, jeśli były konieczne. Pigmenty nakładał w najgłębszych cieniach laserunkowo, natomiast w najwyższych światłach kryjąco. Spośród pigmentów stosował asfalt, brunat kasselski, czerń sadzową, światła natomiast budował używając bieli ołowiowej. W razie potrzeby do-

53 Jedna z części planów, w której ilustrowana głębokość jest podzielona: de Lairesse, Groot Schilderboek, 12, 16, 32, 42, 44, 47, 49, 98, 90, 99, 104, 106, 147, 148, 158, 224, 226, 228, 231-234, 236, 249, 253, 256, 271, 277, 285, 299-301, 316-318, 335, 350, 351, 360, 384, 390, 397, 402, 406, 409, 411.

54 Pole barwne: de Lairesse, Groot Schilderboek, 18, 72, 206, 207, 209-213, 224-228, 230, 232-234, 236, 238-240, 263, 351, 365, 367, 329, 368.

55 Nałożenie równych pól farby bez opracowania detali: de Lairesse, Groot Schilderboek, 9, 11, $13,15,16,18,38-40,268,331,332$.

56 Łagodzenie granic między polami farby przez pędzlowanie suchym pędzlem: de Lairesse, Groot Schilderboek, 9-11, 14, 16, 36, 39, 258, 268.

57 Rozmieszczanie najmocniejszych świateł i najgłębszych cieni: de Lairesse, Groot Schilderbo$e k, 14,39,58$.

58 Najgłębsze cienie: de Lairesse, Groot Schilderboek, 14, 39, 221, 247, 249, 252, 253, 332, 364.

59 Najwyższe światła: de Lairesse, Groot Schilderboek, 12, 14, 39, 137, 210, 213, 221, 223, 254 , 255, 259, 260, 271, 278, 291, 313-315, 332, 361. 
dawał jakieś poprawki. Na koniec zabezpieczał obraz werniksem żywicznym, przygotowanym na bazie naturalnej żywicy.

\section{Wykonanie kopii malarskiej}

Zawarte w traktacie informacje wykorzystano przy sporządzaniu kopii malarskiej ${ }^{60}$. Wybrano do tego celu obraz „Bachus i Ariadna” - jedno z dzieł wykonanych przez de Lairesse’a pod koniec kariery artystycznej, co dawało pewność, że zostało namalowane według wypracowanej przez autora techni$\mathrm{ki}^{\mathrm{i}}$. Zrobienie kopii pozwoliło na poznanie sposobu tworzenia obrazu według de Lairesse'a w praktyce ${ }^{62}$.

Rekonstruując warsztat malarski artysty starano się, opierając się na Het Groot Schilderboek, zastosować współczesne materiały. Zgodnie z przyjętym założeniem, dążono do odtworzenia efektu zbliżonego do oryginału, ale z wykorzystaniem materiałów łatwo dostępnych w naszych czasach. W tym celu opracowano tabele, w których zestawiono pigmenty polecane przez de Lairesse'a oraz pigmenty obecnie dostępne (zob. tabele 1-4). Zrezygnowano z bieli ołowiowej, którą zastąpiono bielą tytanową. Zdecydowano się użyć gotowych produktów dobrych firm, takich jak np. RENESANS, van Gogh bądź CLASSICO. Przygotowano również werniks na bazie żywicy damarowej, z którym mieszano pigmenty. Kiedy była taka potrzeba, spoiwo rozcieńczano olejkiem terpentynowym.

60 Kopię malarską wykonała mgr Ewelina Maciejczyk pod kierunkiem dr hab. Justyny Olszewskiej-Świetlik, prof. UMK.

61 Gerard de Lairesse, „Bachus i Ariadna” (Bacchus and Ariadne) - obraz namalowany prawdopodobnie ok. lat 1676/1682 jako pomniejszona wersja pierwotnie większego dzieła powstałego w latach 1676-1678 dla pałacu Soestdijk holenderskiego Stadhoudera (namiestnika) Wilhelma III (późniejszego Wilhelma III Orańskiego), wykonany techniką olejną na podobraziu płóciennym o wymiarach 68,5 x $51 \mathrm{~cm}$, obecnie w Philadelphia Museum of Art. Por. Roy, Gerard de Lairesse, 77-78, 290, https:/www.mauritshuis.nl/nl-nl/verdiep/de-collectie/ kunstwerken/bacchus-en-ariadne-83/ (dostęp 24 listopada 2015).

62 Dzięki uprzejmości Rijksmuseum w Amsterdamie, za pośrednictwem Pani Dr Elsemieke van Rietschoten uzyskano wgląd do prac badawczych dotyczących obrazu de Lairesse’a pt. „Diana i jej towarzysze” przeprowadzonych na potrzeby referatu wygłoszonego na konferencji w 2013 r. (zob. van Rietschoten et al., "Painting by the rules of art"), m.in. mikrofotografii przekroju stratygraficznego fragmentu pomarańczowej sukni postaci w prawym górnym rogu. Umożliwiło to porównanie założeń zawartych w traktacie z oryginalną pracą de Lairesse’a. Wynikami tych badań posiłkowano się również przy tworzeniu kopii malarskiej zaprezentowanej w niniejszym artykule. Na podstawie analizy wizualnej mikrofotografii przekroju poprzecznego próbki stwierdzono, że zaprawa jest w kolorze brązowym i składa się z mieszaniny czerwieni, brązu, czerni i bieli; na nią położono czerwoną warstwę podmalowania, którą zaizolowano spoiwem olejno-żywicznym, a następnie kolejną warstwę czerwieni i werniks. 
[e]

Retoqueren

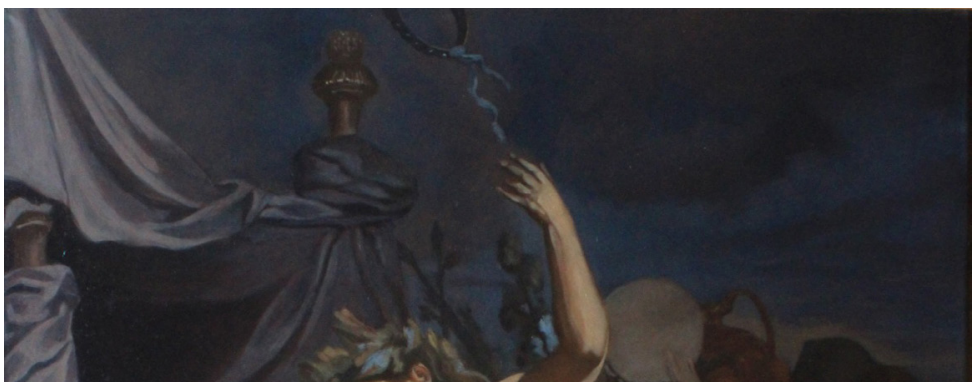

[d]

Aanleggen

i opschilderen

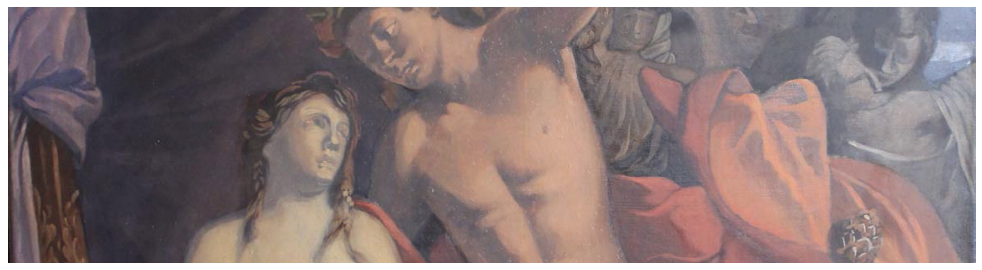

[c]

Doodverwen

(światła)

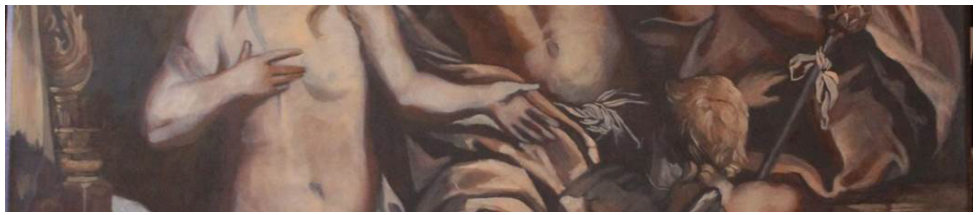

[b]

Doodverwen (cienie)

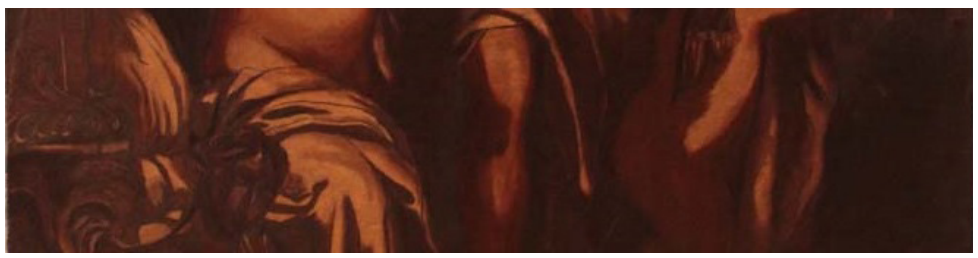

[a]

Podobrazie

(rysunek

na barwnej

zaprawie)

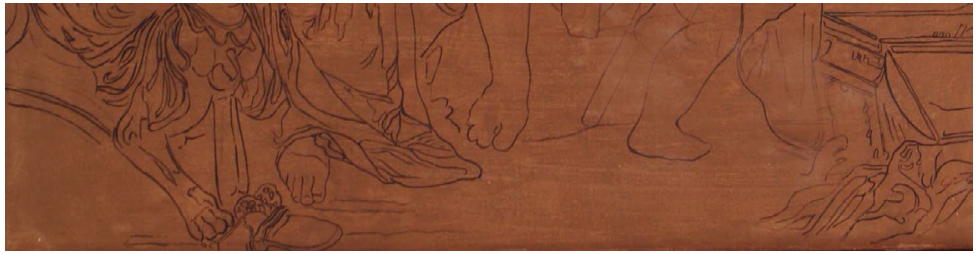

Il. 1. Modelunek malarski według Gerarda de Lairesse - fragmenty etapów wykonania kopii malarskiej. Fot. E. Maciejczyk 
1. Podobrazie: płótno lniane gęsto tkane, o jednakowej grubości nici wątku i osnowy, napięte na fazowane ruchome krosna drewniane o wymiarach 51 x $68 \mathrm{~cm}$ i grubości $2 \mathrm{~cm}$, z klinami do napinania płótna. Krosna są wykonane $\mathrm{z}$ drewna sosnowego, w technice na mikrowczepy (krótkie drewniane elementy łączone na zasadzie zazębiania się).

Przeklejenie: klej glutynowy 5-procentowy (roztwór z żelatyny). Receptura: w $100 \mathrm{~g}$ wody rozpuszczono $20 \mathrm{~g}$ żelatyny. Papier ścierny o gradacji 800 i 1000 .

Zaprawa: emulsyjna brązowa (w dwóch warstwach). Receptura: 1 część (cz.) objętościowa kredy, 1 cz. objętościowa bieli cynkowej (firmy KREMER), 2 cz. objętościowe pigmentów (siena palona, siena naturalna, odrobina czerni firmy KREMER), 2 cz. objętościowe rozpuszczonej w wodzie żelatyny w stosunku 1: 20 i bardzo mała ilość gliceryny, 0,5 cz. objętościowej polimeryzowanego oleju lnianego, w którym stopiono $1 / 4 \mathrm{cz}$. żywicy damarowej. Papier ścierny o gradacji 800 i 1000.

Przeklejenie: klej glutynowy 3-procentowy (roztwór z żelatyny). Receptura: rozcieńczono żelatynę z wodą w stosunku 3: 100.

Rysunek: przeniesiony za pomocą kalki maszynowej, czarnej. Poprawiony czarnym tuszem (rozcieńczanym wodą) za pomocą okrągłego pędzla nr 0/5.

Izolacja: całość zaizolowano cienko werniksem damarowym rozpuszczonym w olejku terpentynowym. Receptura: 10 cz. damary sproszkowanej; 15 cz. olejku terpentynowego; 1 cz. polimeryzowanego oleju lnianego.

Spoiwo: olejek terpentynowy i spoiwo olejno-żywiczne (werniks żywiczny rozcieńczany olejkiem terpentynowym). Receptura: 10 cz. damary sproszkowanej; $15 \mathrm{cz}$. olejku terpentynowego; $1 \mathrm{cz}$. polimeryzowanego oleju lnianego + olejek terpentynowy.

Pędzle: szeroki płaski pędzel z syntetycznego włosia oraz szczeciny; małe okrągłe pędzle z syntetycznego włosia nr 0/5, 1/0, 2/0, 3/0; płaskie pędzle z syntetycznego włosia oraz szczeciny, o różnej wielkości; szersze miękkie pędzle płaskie z włosiem z sierści borsuka.

2. „Doodverwen” („martwe ubarwienie”, podmalowanie modelujące monochromatyczne - brązowe). Opracowanie najgłębszych cieni: pigmenty sjena naturalna (raw siena, firmy Maries), sjena palona (burnt siena, firmy Maries), umbra naturalna (raw umber, firmy CLASSICO), umbra palona (burnt umber, firmy CLASSICO), odrobina cynobru (vermilion, firmy RENESANS); spoiwo - olejek terpentynowy. 
3. „Doodverwen” („martwe ubarwienie”, podmalowanie modelujące monochromatyczne - brązowe). Opracowanie najwyższych świateł: pigmenty - biel tytanowa (titanium white, firmy RENESANS), sjena naturalna (raw siena, firmy Maries), sjena palona (umber siena, firmy Maries), umbra naturalna (raw umber, firmy CLASSICO), odrobina cynobru (vermilion, firmy RENESANS); spoiwo - olejek terpentynowy.

4. „Aanleggen” $i$ „opschilderen” (nakładanie farby i malowanie, opracowanie warstwy malarskiej). Półlaserunki: pigmenty - biel tytanowa (titanium white, firmy RENESANS), ochra żółta (yellow ochre, firmy RENESANS), ochra jasna (yellow light ochre), żółcień neapolitańska (Naples yellow, firmy van Gogh), cynober (vermilion, firmy RENESANS), ultramaryna (ultramarine, firmy Maries), umbra palona (burnt umber, firmy CLASSICO); spoiwo olejno-żywiczne (werniks żywiczny rozcieńczany olejkiem terpentynowym).

Laserunek $\boldsymbol{w}$ partii karnacji: ultramaryna (ultramarine, firmy Maries); spoiwo - olejno-żywiczne (werniks żywiczny rozcieńczany olejkiem terpentynowym).

5. „Retoqueren” (retuszowanie, opracowanie najwyższych świateł i cieni). Pigmenty: jasna ochra (light ochre, firmy RENESANS), cynober (primary vermilion, firmy RENESANS); cienie: brunat kasselski (Van Dyck brown, firmy RENESANS), asfalt (asphalt), czerń sadzowa (lamp black, firmy van Gogh); spoiwo - olejno-żywiczne (werniks żywiczny rozcieńczany olejkiem terpentynowym).

Werniks końcowy: żywiczny (damara rozpuszczona w olejku terpentynowym). Receptura: 10 cz. damary sproszkowanej; 15 cz. olejku terpentynowego; 1 cz. polimeryzowanego oleju lnianego.

\section{Podsumowanie}

Na podstawie analizy traktatu Het Groot Schilderboek, literatury przedmiotu, wiedzy z zakresu technologii i technik malarskich oraz przeprowadzonej rekonstrukcji malarskiej udało się bliżej rozpoznać warsztat malarski Gerarda de Lairesse'a. Artysta zalecał płócienne podobrazia napinane na drewniane ramy, sporządzone z dużą starannością. Zgodnie z jego wskazówkami modelunek malarski powinien być wykonany w technice wielowarstwowej. Formę należało budować od najgłębszych cieni poprzez półtony do najwyższych świateł. Pracę dzielił na kilka etapów: podmalowanie („doodverwen”), nakładanie farby (,aanleggen”), malowanie („opschilderen”) oraz opracowywanie 


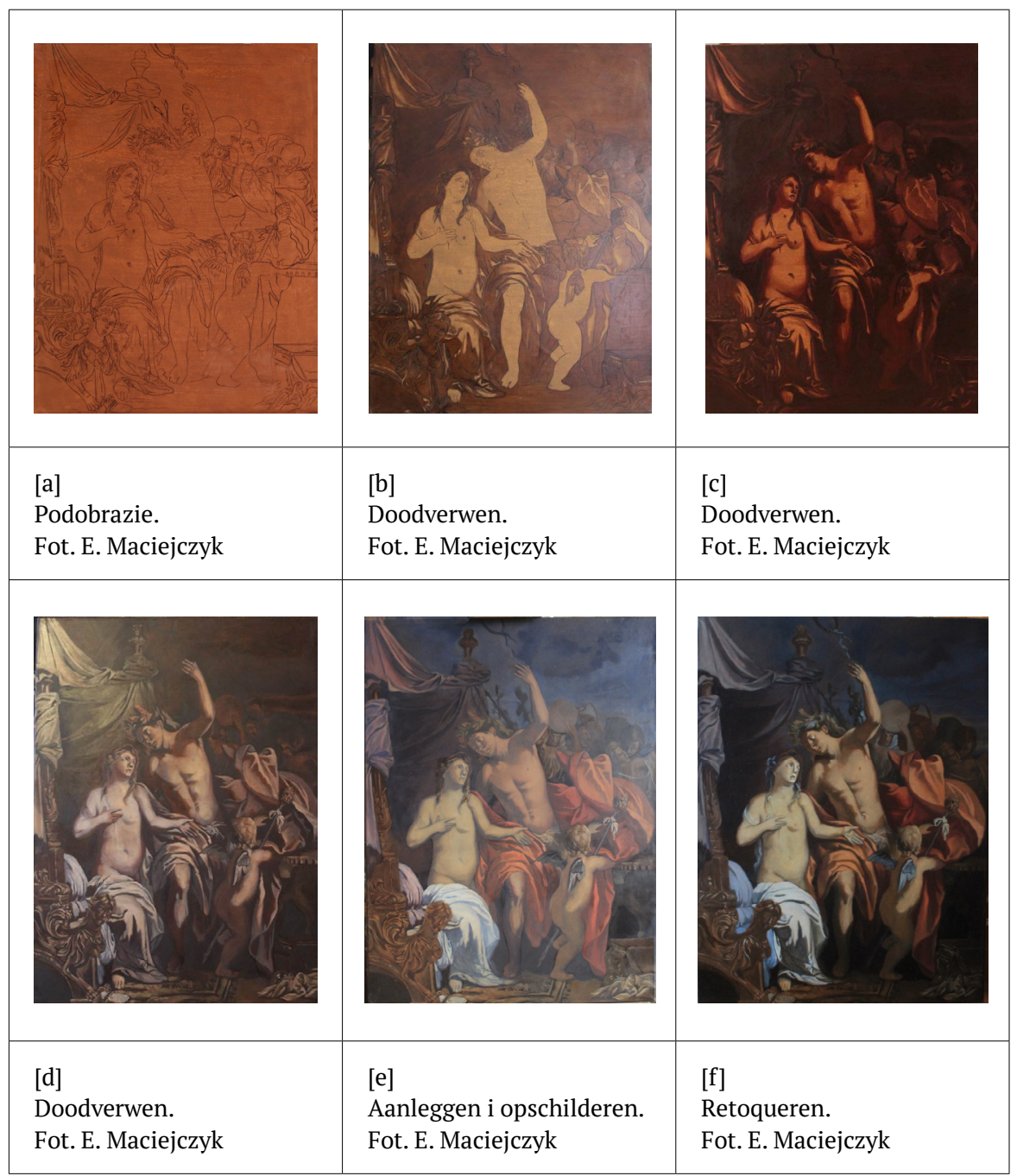

Il. 2. Tabela - modelunek malarski według Gerarda de Lairesse - etapy wykonania kopii malarskiej. Fot. E. Maciejczyk

najwyższych świateł i cieni („retoqueren”) ${ }^{63}$. Dla pierwszej warstwy kryjącego podmalowania należało użyć pigmentów zmieszanych z olejkiem terpentynowym - w ten sposób uzyskiwało się farbę ,,chudą”, na którą można było potem nakładać dalsze warstwy malarskie z bardziej ,,tłustym” spoiwem.

${ }_{63}$ Zob. il. 1a-e, 2a-f. 
Kolejne warstwy malarskie powinny być nakładane półkryjąco i laserunkowo. Dla tych warstw należało mieszać pigmenty ze spoiwem olejno-żywicznym - farbę można było rozcieńczyć olejkiem terpentynowym. Zastosowanie takiego spoiwa zapewniało też równomierny i szybki czas wysychania powłoki malarskiej, która charakteryzowała się dobrą trwałością, przejrzystością i głębią kolorów.

Wykonanie kopii udowodniło, że możliwe jest praktyczne odtworzenie techniki malarskiej na podstawie pracy teoretycznej. Dogłębna analiza traktatu nie wyczerpuje jednak w pełni zagadnienia warsztatu de Lairesse'a. Nie istniała możliwość przebadania obrazów artysty, co dostarczyłoby bardziej szczegółowych informacji ${ }^{64}$.

Interesującą sprawą byłoby sprawdzenie, czy traktat de Lairesse'a miał wpływ na technikę modelunku gdańskich malarzy XVII i XVIII stulecia. Do wieku XVIII polscy artyści zdobywali doświadczenie głównie w ramach systemu cechowego. W późniejszym okresie sytuacja znacząco się zmieniła - zatrudniali ich zamożni mecenasi, wielu twórców otoczył opieką król Stanisław August Poniatowski. Często też na własną rękę kształcili się u malarzy za granicą, żeby w późniejszych latach wrócić do Polski. Ciekawym przykładem jest twórczość braci Teodora i Krzysztofa Lubienieckich, którzy byli uczniami Gerarda de Lairesse'a ${ }^{65}$. Wiadomo, że Teodor na starość wrócił do kraju. Traktat de Lairesse'a (wydany przez Dawida Mortiera w latach 1714-1715) znalazł się w XVIII wieku w zbiorach Biblioteki Rady Miejskiej (obecnie Biblioteka Gdańska PAN) ${ }^{66}$. Traktaty teoretyczne licznie powstające w XVII wieku w środowisku holenderskim znane były w całej Europie, w tym także w Gdańsku, Elblągu, Toruniu ${ }^{67}$. Dzieło de Lairesse’a było tu analizowane głównie pod kątem zagadnień natury technicznej. Porównanie uzyskanych informacji z wynikami badań malarstwa gdańskiego z XVII i XVIII wieku (zob. tab. 4$)^{68}$ przyniosło ciekawe obserwacje. W Gdańsku podobnie jak u de Lairresse’a sto-

64 Wprawdzie istniała możliwość wglądu do wyników badań jednego obrazu de Lairesse’a, jednak to zbyt mało by określić jego technikę. Zob. przypis 63 .

65 Houbraken, De groote schouburgh, 329.

66 Portret ponad wszystko, 245; Mosingiewicz i Okoń, „O obrazach”, 109.

67 Mosingiewicz i Okoń, „O obrazach”, 43.

68 Zob. wyniki badań wybranych dzieł malarstwa gdańskiego: Józef Flik, „Portrety Jana Heweliusza z Gdańska i Oxfordu - studium warsztatu malarskiego”, Ochrona Zabytków 2 (1995): 169-180; Justyna Olszewska-Świetlik, Gdański warsztat malarski schyłku XVII i XVIII wieku na przykładach wybranych portretów przedstawiających protestanckich duchownych (Torun: Wydawnictwo Naukowe Uniwersytetu Mikołaja Kopernika, 2010), 104-106; Justyna Olszewska-Świetlik, Ewelina Pawlak, „Warsztat malarski cyklu obrazów emporowych z kościoła 
sowano podobrazia płócienne z barwnymi czerwonymi zaprawami. Paleta malarska oraz spoiwa nie wykazują istotnych różnic. W malarstwie gdańskim do tej pory nie zidentyfikowano natomiast żółtych pigmentów, które wymienia de Lairesse, takich jak aurypiment, żółcień neapolitańska, realgar. W obrazach gdańskich dominowała żółcień cynowo-ołowiowa ${ }^{69}$. Różnice dotyczą także modelunku malarskiego, który charakteryzuje się mniejszą ilością warstw malarskich względem zaleceń de Lairesse’a. Podmalowanie wzorem wcześniejszej tradycji niderlandzkiej wykonywano szarością i w kolorze lokalnym, ale wykorzystywano również czerwony kolor zaprawy, na którym opracowanie wykonywano brązem, co odpowiada podmalowaniom stosowanym przez de Lairesse’a („doodverwen”) ${ }^{70}$.

Wyniki analiz zawartych w artykule mogą być wykorzystane przy interpretacji technologii i techniki malarskiej innych dzieł, ale przede wszystkim do prawidłowego planowania i wykonania rekonstrukcji konserwatorskich. Nie bez znaczenia jest także możliwość rozpoznania wpływu traktatu de Lairesse'a w zaprezentowanym w niniejszej pracy aspekcie techniki malarskiej na dzieła malarskie z terenów dawnych Prus Królewskich.

pod wezwaniem św. Jana w Gdańsku”, Acta Universitatis Nicolai Copernici, Zabytkoznawstwo i Konserwatorstwo 40 (2011): 195-222.

69 Nie można określić rodzaju stosowanych w szkole gdańskiej żółtych i brązowych barwników organicznych ze względu na ograniczenia dotyczące głównie ilości pozyskanego materiału do badań.

70 De Lairesse, Groot schilderboek, 12-13. 

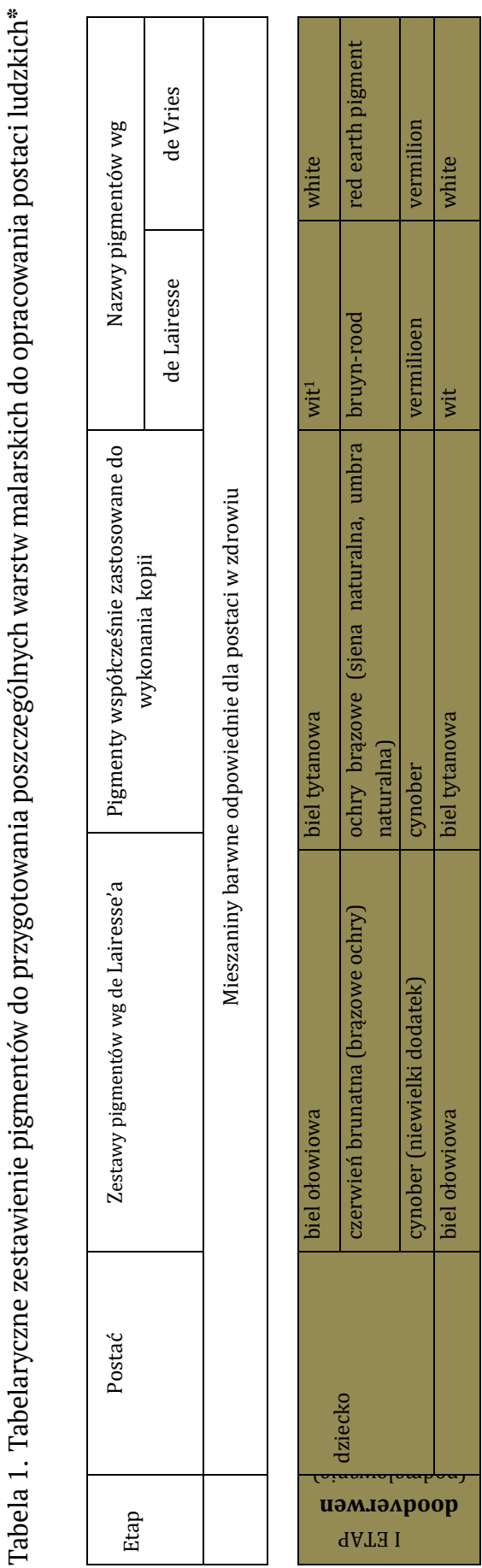

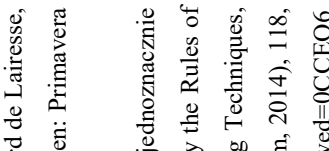

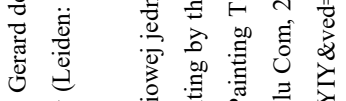

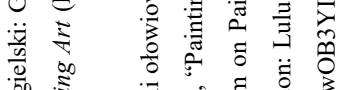

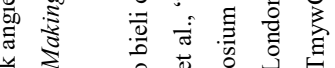

离芯

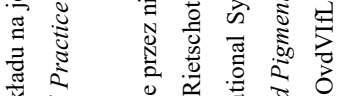

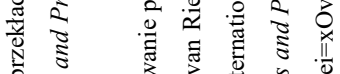

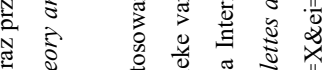

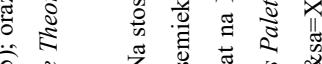

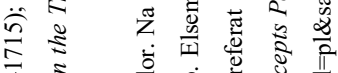

I 5 क

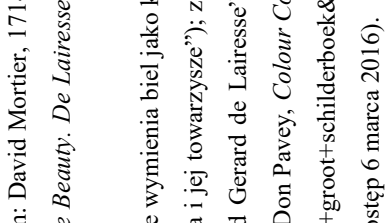

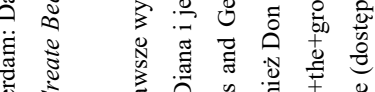

ए

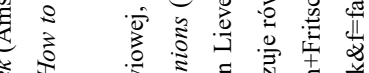

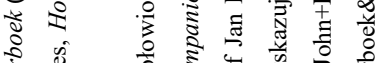

5 造

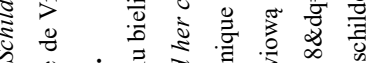

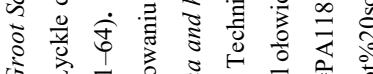

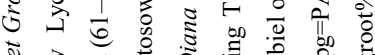

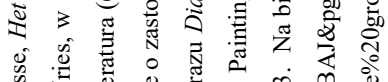

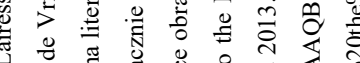

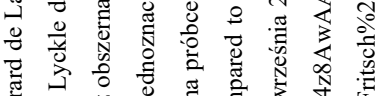

焉

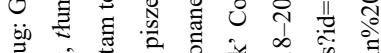

है

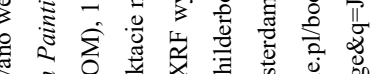

సै

品守

运

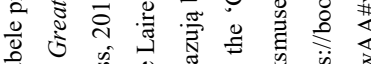

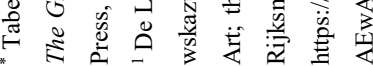



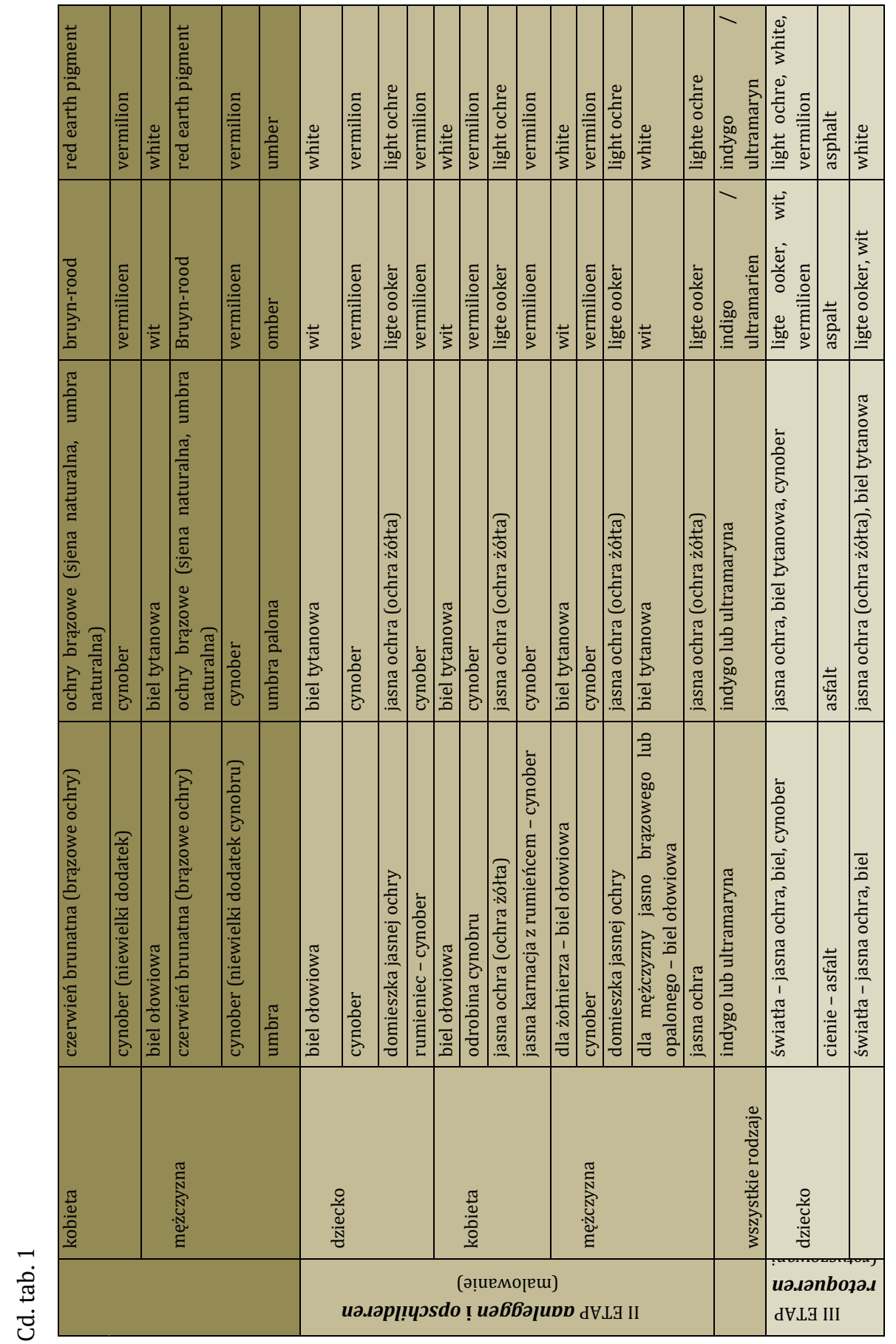

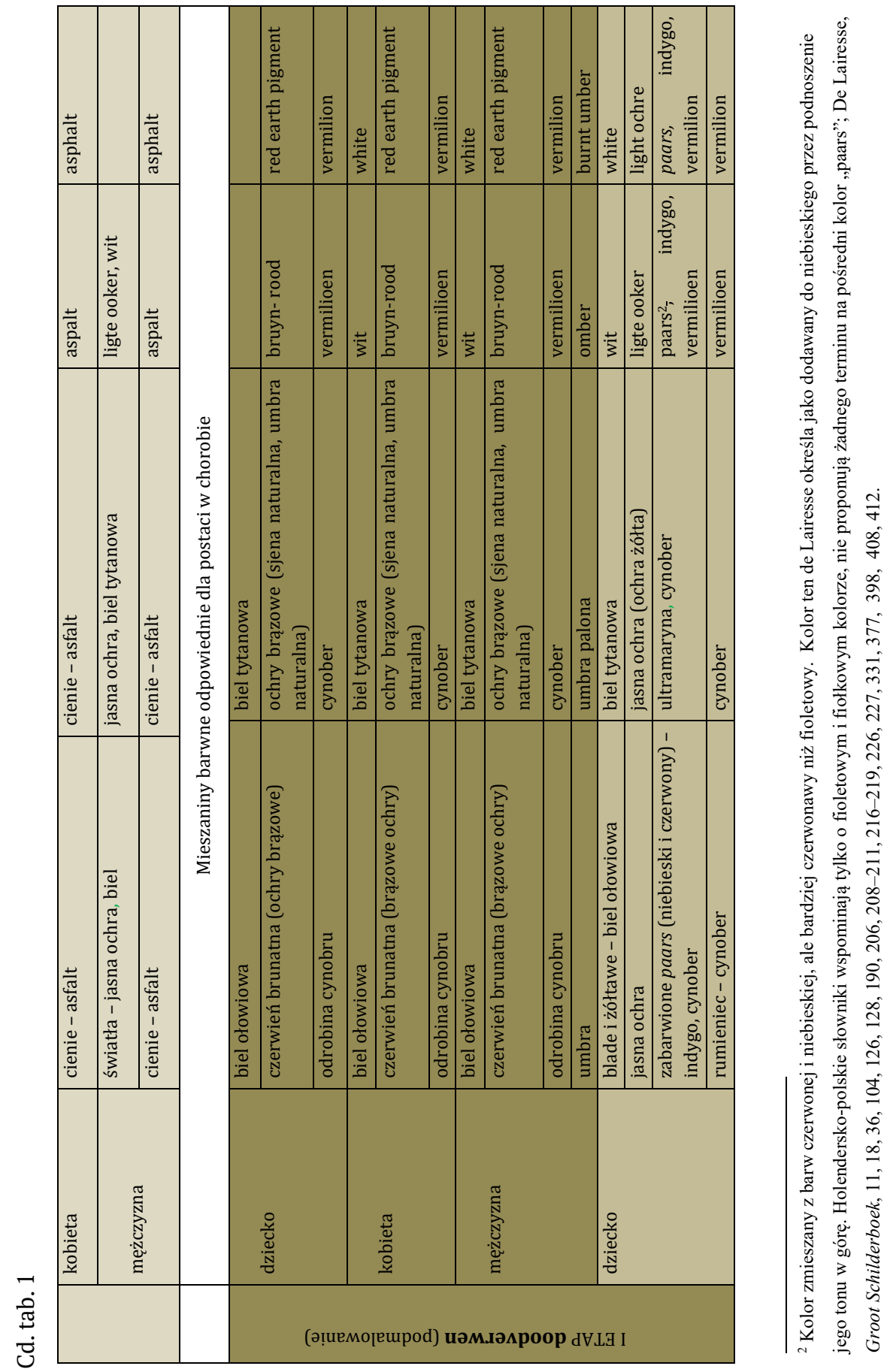


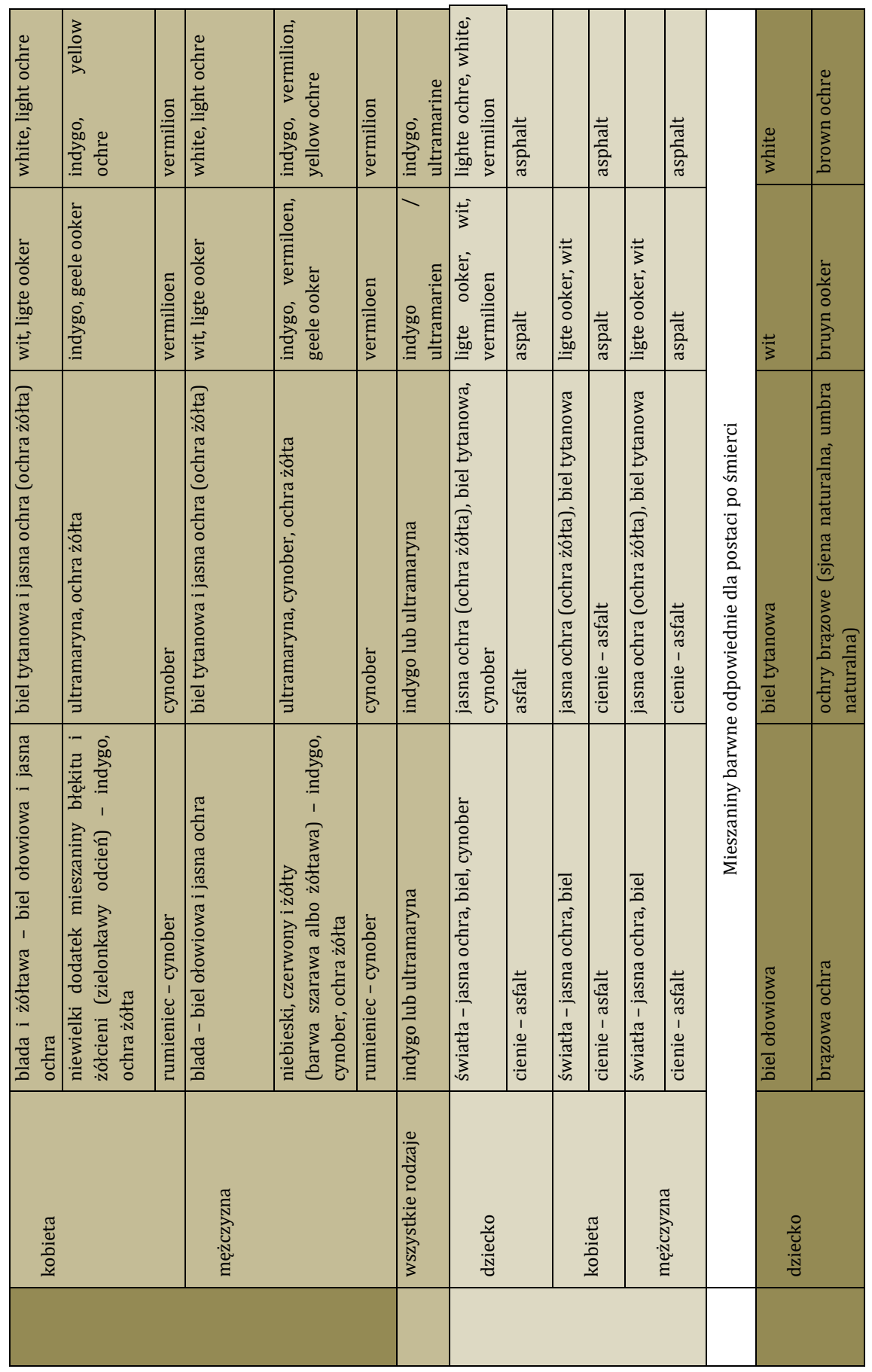




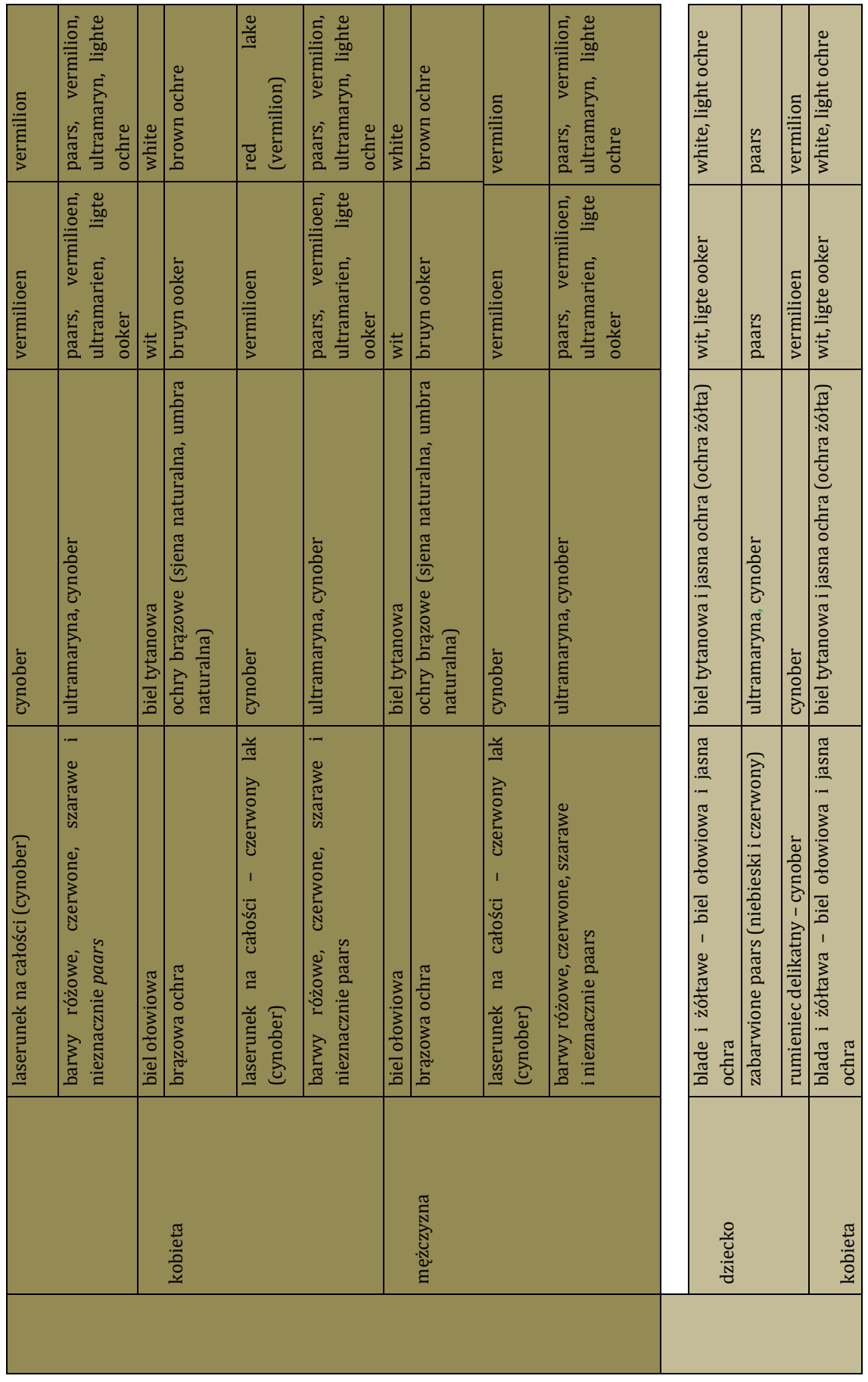




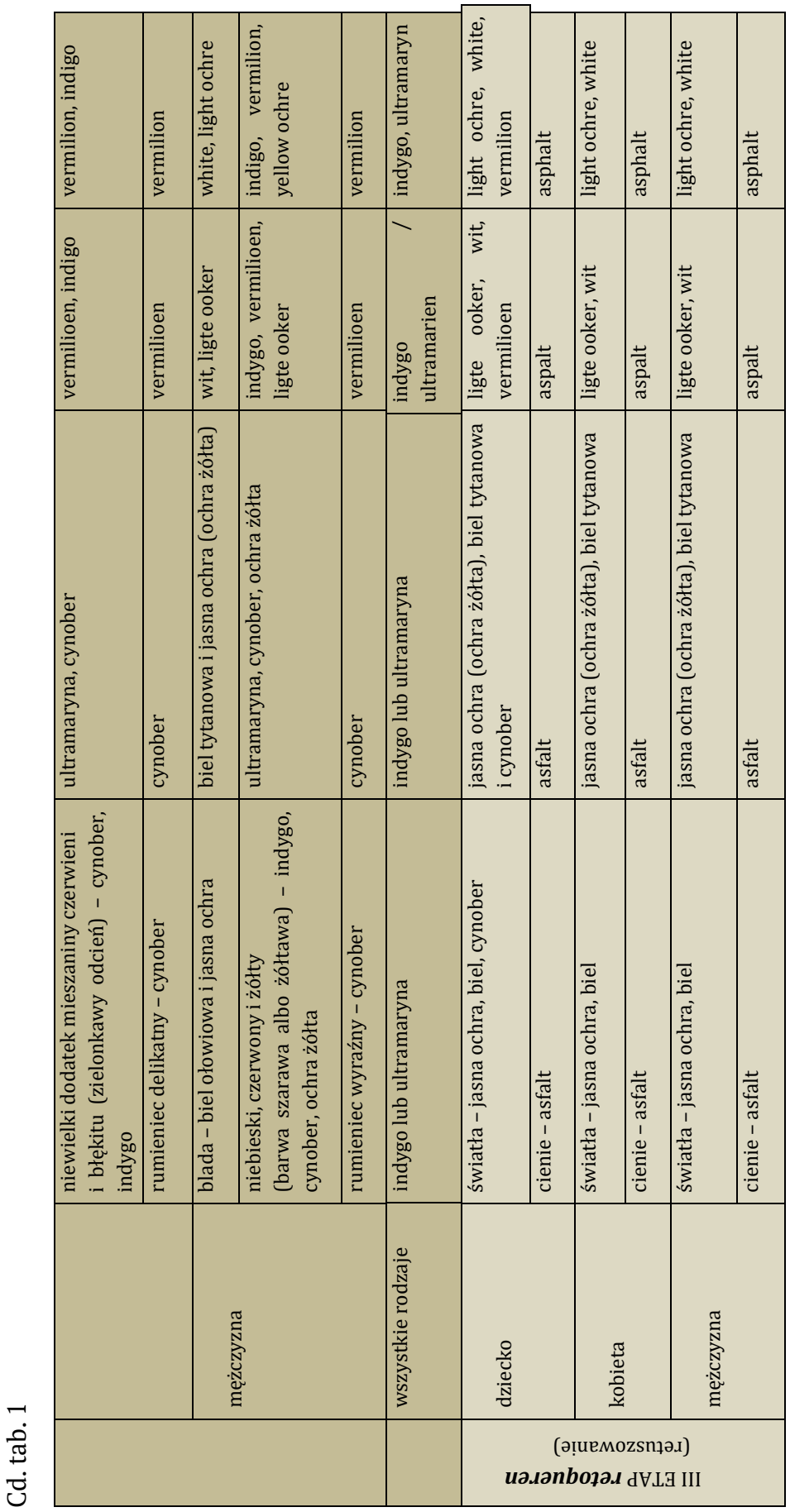




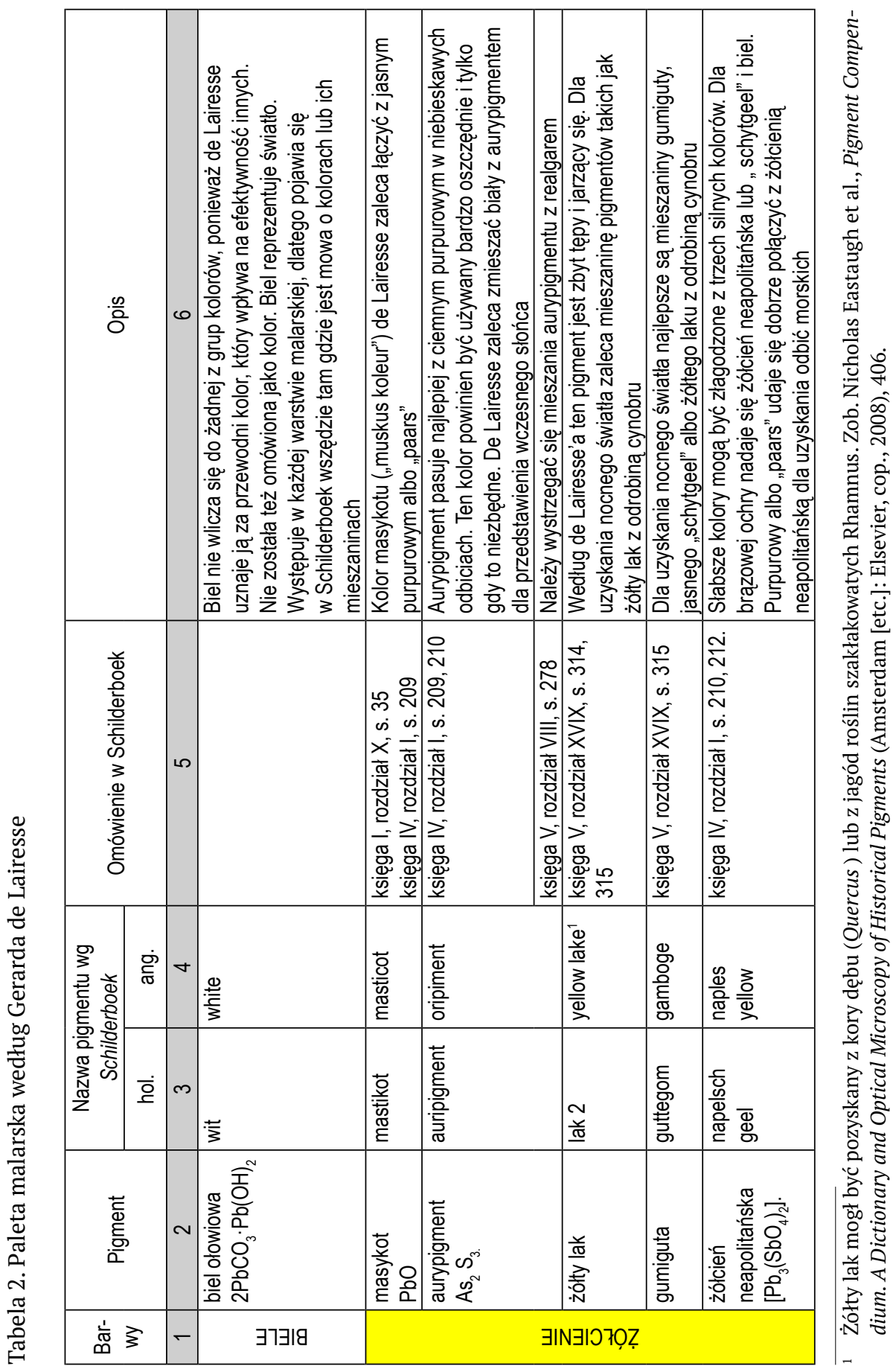




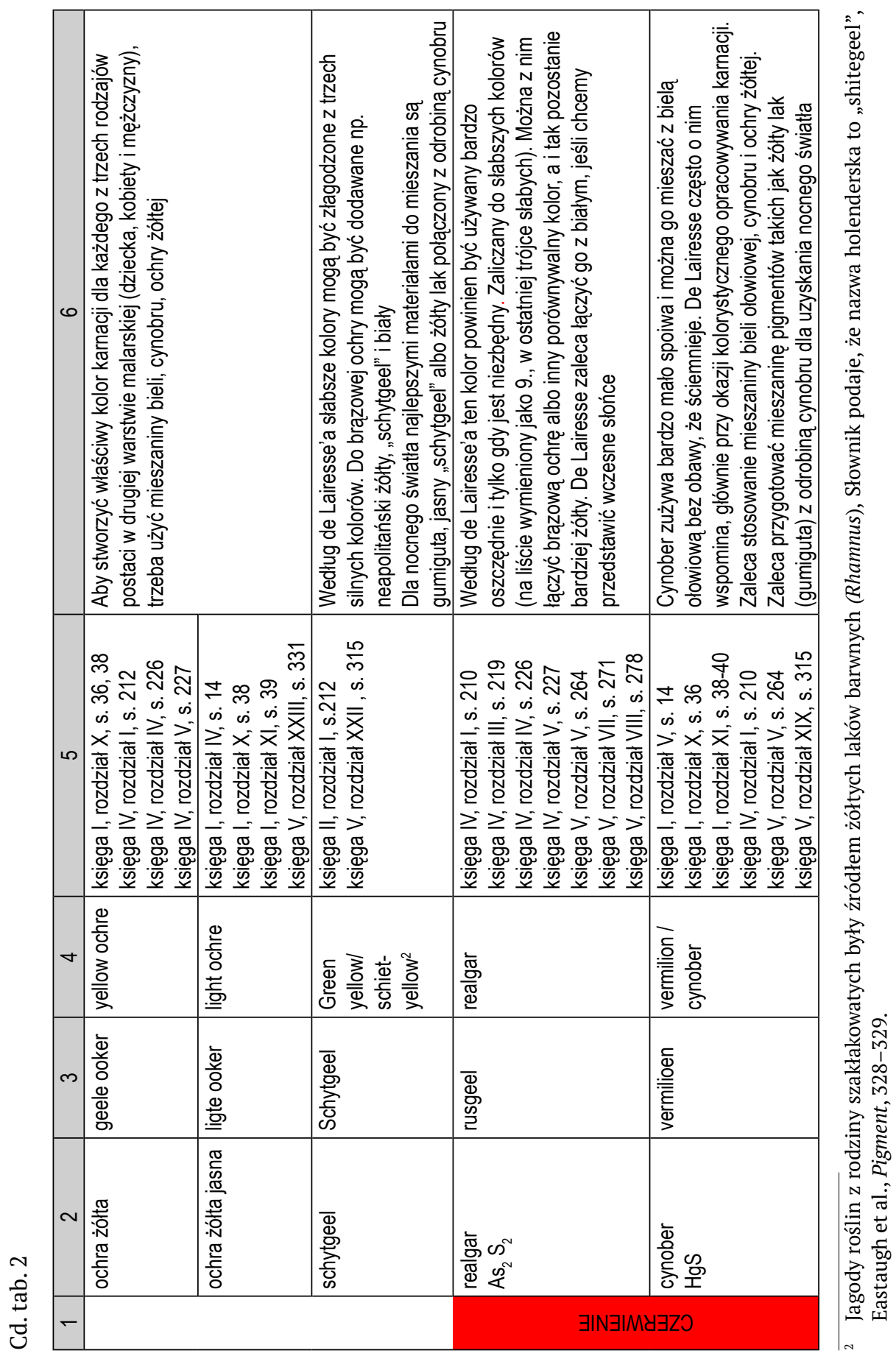




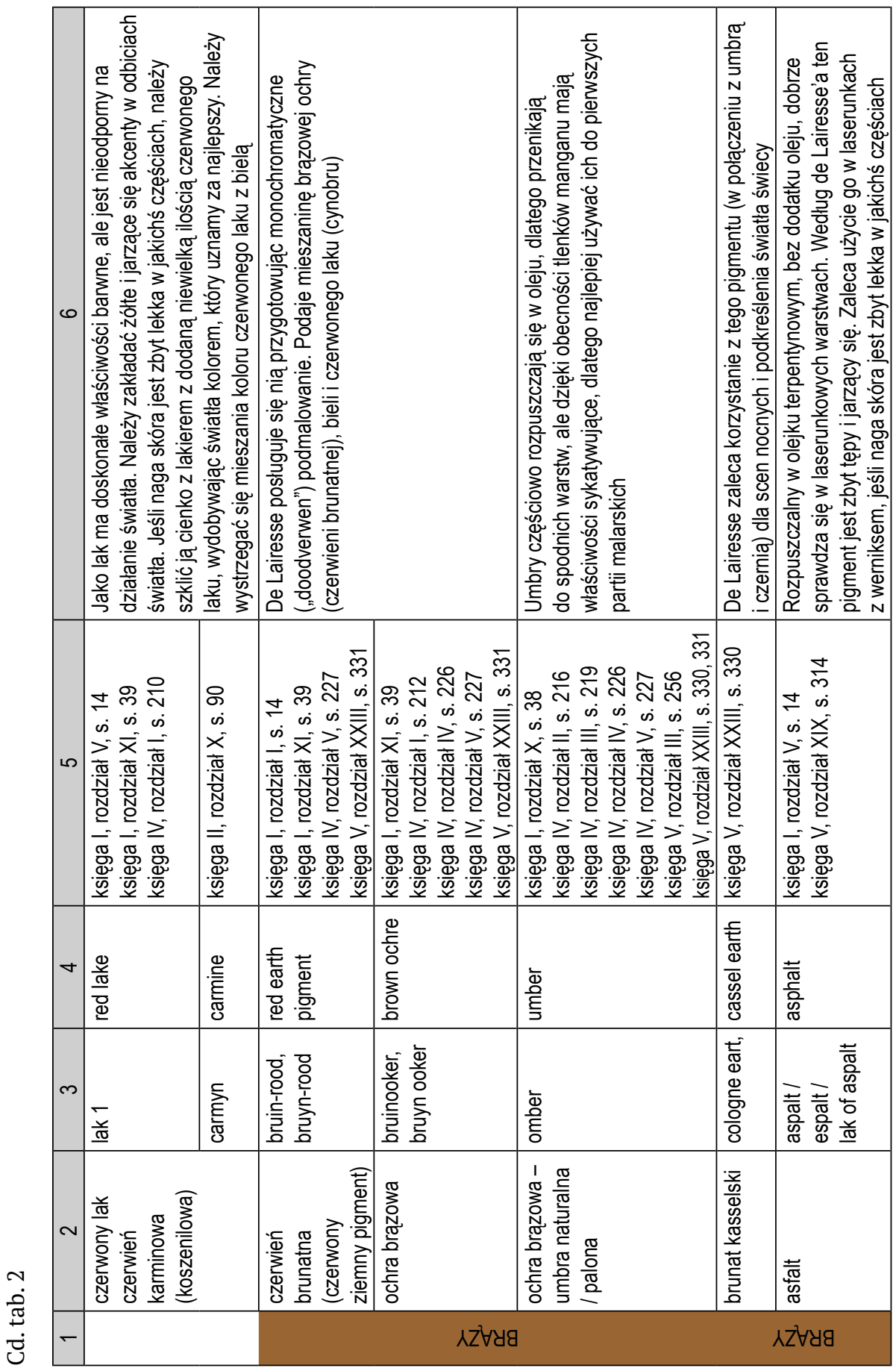




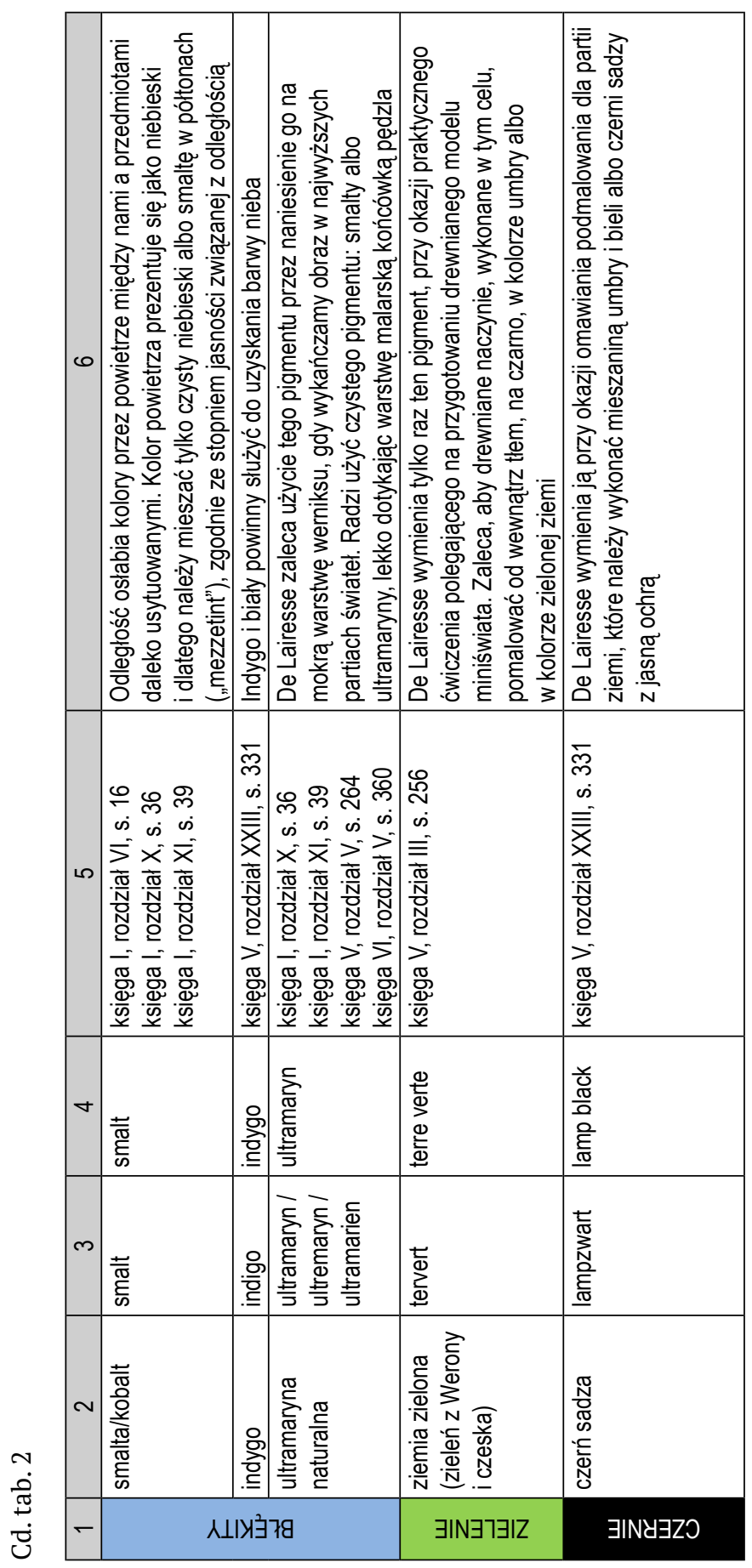


Tabela 3. Tabelaryczne zestawienie kolorów głównych i rozbitych

\begin{tabular}{|c|c|c|c|}
\hline Kolory & Nazwa & Znaczenie symboliczne & Użycie \\
\hline $\begin{array}{l}\text { Podstawowe } \\
\text { (główne) - } \\
\text { "primaire" } \\
\text { ("hoofd") }\end{array}$ & $\begin{array}{l}\text { - żółty } \\
\text { - czerwony } \\
\text { - niebieski } \\
\text { biały i czarny nie są uzna- } \\
\text { wane za kolory, ale sa } \\
\text { nazywane przewodnimi, } \\
\text { ponieważ inne kolory } \\
\text { sa nieskuteczne bez ich } \\
\text { pomocy }\end{array}$ & $\begin{array}{l}\text { - żółty oznacza Wspania- } \\
\text { łość i Chwałe } \\
\text { - czerwony oznacza } \\
\text { Przemoc albo Miłość } \\
\text { - niebieski oznacza } \\
\text { Boskość } \\
\text { - biały reprezentuje świa- } \\
\text { tło, czarny ciemność }\end{array}$ & $\begin{array}{l}\text { te kolory mogą być uzyte } \\
\text { jednocześnie aby stworzyć } \\
\text { głębie - żółty w centrum, } \\
\text { czerwony obok niego, } \\
\text { a niebieski na dalszym } \\
\text { planie }\end{array}$ \\
\hline $\begin{array}{l}\text { Rozbite } \\
\text { (słabe) - } \\
\text { ",gebrooken } \\
\text { koleur" } \\
\text { (,zwak") }\end{array}$ & $\begin{array}{l}\text { - zielony (jest zrobiony } \\
\text { z niebieskiego i żółtego) } \\
\text { - purpurowy (jest stwo- } \\
\text { rzony z czerwonego } \\
\text { z domieszką innego } \\
\text { głównego koloru) } \\
\text { - „paars” (jest zrobiony } \\
\text { z czerwonego i niebie- } \\
\text { skiego) }\end{array}$ & $\begin{array}{l}\text { - purpurowy oznacza } \\
\text { Władzé i Suwerenność } \\
\text { - „paars” oznacza Ule- } \\
\text { głość } \\
\text { - zielony oznacza Niewole }\end{array}$ & $\begin{array}{l}\text { trzy rozbite kolory moga } \\
\text { być zorganizowane podob- } \\
\text { nie, przez umieszczanie } \\
\text { purpurowego na pierw- } \\
\text { szym planie, paars za nim } \\
\text { i zielonego na najdalszym } \\
\text { planie, ponieważ jest } \\
\text { najsłabszy }\end{array}$ \\
\hline
\end{tabular}


Tabela 4. Porównanie technologii i techniki szkoły gdańskiej z XVII i XVIII wieku z założeniami traktatu o malarstwie - Het Groot Schilderboek

\begin{tabular}{|c|c|c|c|}
\hline $\begin{array}{l}\text { Rodzaj } \\
\text { informacji }\end{array}$ & $\begin{array}{l}\text { Szkoła gdańska - } \\
\text { wiek XVII }\end{array}$ & $\begin{array}{l}\text { Szkoła gdańska - } \\
\text { wiek XVIIII }\end{array}$ & Traktat \\
\hline 1 & 2 & 3 & 4 \\
\hline Nazwa & warsztat gdański & warsztat gdański & $\begin{array}{l}\text { Gerard de Lairesse, } \\
\text { Het Groot Schilderboek, } \\
\text { Amsterdam }\end{array}$ \\
\hline Datowanie & XVII w. & XVIII w. & 1707 \\
\hline Podobrazie & płótno Iniane & płótno Iniane & $\begin{array}{l}\text { płótno Iniane } \\
\text { panele drewniane }\end{array}$ \\
\hline Zaprawa & $\begin{array}{l}\text { czerwona } \\
\text { spoiwo - emulsja } \\
\text { wypełniacz: czerwona } \\
\text { glinka żelazowa, czerń } \\
\text { roślinna }\end{array}$ & $\begin{array}{l}\text { czerwona } \\
\text { spoiwo - emulsja: kaze- } \\
\text { ina, olej Iniany } \\
\text { wypełniacz: czerwona } \\
\text { glinka żelazowa, kreda, } \\
\text { czerń roślinna, żółcień } \\
\text { ołowiowa - glejta, biel } \\
\text { ołowiowa }\end{array}$ & $\begin{array}{l}\text { czerwono-brazowa } \\
\text { (w dwóch warstwach) } \\
\text { spoiwo - emulsja } \\
\text { wypełniacz: kreda, czerń } \\
\text { roślinna, czerwień, brązy }\end{array}$ \\
\hline Rysunek & biała kreda (?) & czarna farba, pędzel & węgiel, czarna farba, pędzel \\
\hline $\begin{array}{l}\text { Spoiwo } \\
\text { warstwy } \\
\text { malarskiej }\end{array}$ & $\begin{array}{l}\text { emulsja typu woda } \\
\text { w oleju } \\
\text { olej Iniany, żywica } \\
\text { naturalna }\end{array}$ & $\begin{array}{l}\text { emulsja typu woda w ole- } \\
\text { ju: olej Iniany, kazeina; } \\
\text { olejno-żywiczne: olej } \\
\text { Iniany, żywica naturalna; } \\
\text { olejne: olej Iniany }\end{array}$ & $\begin{array}{l}\text { olejno-żywiczne: olej, ży- } \\
\text { wica naturalna, terpentyna } \\
\text { wenecka } \\
\text { olejek terpentynowy }\end{array}$ \\
\hline Podmalowanie & $\begin{array}{l}\text { szare - grisaillowe } \\
\text { kolory lokalne }\end{array}$ & $\begin{array}{l}\text { szare - grisaillowe, } \\
\text { kolory lokalne }\end{array}$ & $\begin{array}{l}\text { Czerwono-brazowe (mo- } \\
\text { nochromatyczne) }\end{array}$ \\
\hline
\end{tabular}

Zestawienie wykonano na podstawie badań oraz publikacji: Józef Flik, „Portrety Jana Heweliusza z Gdańska i Oxfordu - studium warsztatu malarskiego", Ochrona Zabytków 2 (1995): s. 169-180; Justyna Olszewska-Świetlik, Gdański warsztat malarski schyłku XVII i XVIII wieku na przykładach wybranych portretów przedstawiających protestanckich duchownych (Toruń: Wydawnictwo Naukowe UMK, 2010), 104-106; Justyna Olszewska-Świetlik, Ewelina Pawlak, „Warsztat malarski cyklu obrazów emporowych z kościoła pod wezwaniem św. Jana w Gdańsku”, Acta Universitatis Nicolai Copernici. Zabytkoznawstwo i Konserwatorstwo 40 (2011): 195-222.

1 Wypełniacze określono na podstawie analizy mikrofotografii przekroju próbki pobranej z obrazu de Lairesse'a Diana and her companions („Diana i jej towarzysze”): widoczne są czarne, czerwone, białe, ugrowe ziarna pigmentów. Zob. Elsemieke van Rietschoten et al., "Painting by the Rules of Art; the 'Groot Schilderboeck' Compared to the Painting Technique of Jan Lievens and Gerard de Lairesse”, referat na International Symposium on Painting Techniques, Rijksmuseum, Amsterdam, 18-20 września 2013. 
Cd. tab. 4

\begin{tabular}{|c|c|c|c|}
\hline 1 & 2 & 3 & 4 \\
\hline \multirow{29}{*}{$\begin{array}{l}\text { Pigmenty } \\
\text { i barwniki } \\
\text { organiczne }\end{array}$} & biel ołowiowa & biel ołowiowa & biel ołowiowa \\
\hline & żółcień cynowo-ołowiowa & żółcień cynowo-ołowiowa & - \\
\hline & - & żółcień ołowiowa & masykot \\
\hline & - & - & aurypigment \\
\hline & - & - & schytgeel \\
\hline & - & - & żółcień neapolitańska \\
\hline & - & - & żółty lak (żółcień organiczna) \\
\hline & - & - & ochra żółta \\
\hline & - & - & realgar \\
\hline & żółcień żelazowa & żółcień żelazowa & - \\
\hline & czerwień żelazowa & czerwień żelazowa & - \\
\hline & cynober & cynober & cynober \\
\hline & minia & minia & - \\
\hline & czerwień organiczna & $\begin{array}{l}\text { Czerwień organiczna } \\
\text { (karmin, sporadycznie } \\
\text { kraplak) }\end{array}$ & $\begin{array}{l}\text { czerwony lak (czerwień } \\
\text { organiczna, karmin) }\end{array}$ \\
\hline & - & - & czerwień brunatna \\
\hline & - & brązy żelazowe & - \\
\hline & - & umbra & umbra \\
\hline & malachit naturalny & - & - \\
\hline & - & zieleń miedziowa & - \\
\hline & ziemia zielona & Ziemia zielona & ziemia zielona \\
\hline & - & $\begin{array}{l}\text { Zielono-niebieski barwnik } \\
\text { organiczny }\end{array}$ & - \\
\hline & azuryt naturalny & - & - \\
\hline & smalta & - & smalta \\
\hline & indygo & indygo & indygo \\
\hline & - & - & ultramaryna naturalna \\
\hline & - & - & brunat kasselski \\
\hline & - & - & asfalt \\
\hline & czerń roślinna & czerń roślinna & - \\
\hline & - & - & czerń sadza \\
\hline Technika & $\begin{array}{l}\text { technika wielowarstwo- } \\
\text { wa; podmalowanie } \\
\text { temperowe, wykończe- } \\
\text { nie olejne lub olejno- } \\
\text {-żywiczne }\end{array}$ & $\begin{array}{l}\text { technika wielowarstwo- } \\
\text { wa; podmalowanie } \\
\text { szarością oraz w kolorze } \\
\text { lokalnym }\end{array}$ & $\begin{array}{l}\text { technika wielowarstwowa; } \\
\text { podmalowanie czerwono- } \\
\text { brązowe (monochroma- } \\
\text { tyczne) }\end{array}$ \\
\hline
\end{tabular}




\section{Bibliografia}

\section{Druki i opracowania}

Białostocki, Jan. Studia i rozprawy z dziejów sztuki i myśli o sztuce. Warszawa: PWN, 1959. Białostocki, Jan. Teoretycy, historiografowie i artyści o sztuce. 1600-1700. Warszawa: PWN, 1994.

Bryan, Michael. Dictionary of painters and engravers, biographical and critical. T. 50 A-K. London: George Bell and sons, 1886. https://archive.org/details/cu31924092716962. Dostęp 4 marca 2016.

Dolders, Arno. “Some Remarks on Lairesse's Groot Schilderboek”. Simiolus. Netherlands Quarterly for the History of Art 15 (1985) 3/4: 197-220. http://www.jstor.org/discover $/ 10.2307 / 3780693$ ?sid=21105713432483\&uid=387572221 \&uid=60\&uid=70\&ui d=3\&uid=2 \&uid=387572231 \&uid=2134. doi: 10.2307/3780693. Dostęp 26 września 2014.

Eastaugh, Nicholas, Valentine Walsh, Tracey Chaplin, i Ruth Siddall. Pigment Compendium. A Dictionary and Optical Microscopy of Historical Pigments. Amsterdam: Elsevier cop., 2008.

Flik, Józef. „Portrety Jana Heweliusza z Gdańska i Oxfordu - studium warsztatu malarskiego". Ochrona Zabytków 48 (1995) 2: 169-180.

Genaille, Robert. Encyklopedia malarstwa flamandzkiego i holenderskiego. Aktualizacja, uzupetnienie i nowe hasła. Tłumaczenie Maciej Monkiewicz i Antoni Ziemba. Warszawa: PWN, 2001.

Hak, Bob. The Golden Age. Dutch Painters of the Seventeenth Century. London: Stewart, Tabori \& Chang, 1984.

Hammann, Barbara. Hans Hinrich Rundt, ein deutscher Maler an der Wende vom 17, zum 18. München: Ludwig Maximilian University, 1974. http://de.dbpedia.org/page/ Hans_Hinrich_Rundt. Dostęp 4 marca 2016.

Houbraken, Arnold. De groote schouburgh der Nederlantsche konstschilders en schilderessen. T. 3. Amsterdam: B. M. Israel, 1976. http://www.dbnl.org/tekst/houb005groo01_01/houb005groo01_01_0353.php. Dostęp 27 listopada 2014.

Johnson, Horton A. “Gerard de Lairesse: Genius Among the Treponemes”. Journal of the Royal Society of Medicine 97 (2004) 6: 301-303. http://www.ncbi.nlm.nih.gov/pmc/ articles/PMC1079501/. Dostęp 28 października 2014.

Kemmer, Claus. 'In Search of Classical Form: Gerard de Lairesse's 'Groot Schilderboek' and Seventeenth-Century Dutch Genre Painting”. Simiolus. Netherlands Quarterly for the History of Art 26 (1988) 1/2: 87-115. http://www.jstor.org/stable/3780872. Dostęp 28 października 2014.

Lairesse, Gerard de. Het Groot Schilderboek. Eerste deel. Amsterdam: Willem de Coup, 1707. http://www.europeana.eu/portal/en/record/9200143/BibliographicResource_2000069511050.html. Dostęp 25 marca 2017 
Lairesse, Gerard de. Groot Schilderboek. Amsterdam: Hendrick Desbordes, 1712. http:// www.dbnl.org/tekst/lair001groo01_01/index.php. Dostęp 26 września 2014.

Lairesse, Gerard de. Groot Schilderboek, waar in de Schilderkonst [...] in al haar deelen grondog werd onderweezen, ook door redeneeringen en printverbeeldingen verklaard

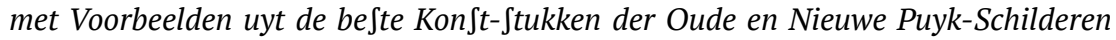
bevestigd. En derzelver Welen Misftand aangeweezen door. T. 1-2. Amsterdam: David Mortier, 1714-1715. http://digi.ub.uni-heidelberg.de/diglit/lairesse1701bd1/0016/ scroll?sid=814f3dbd17aac04cd9f65d6a905a6e50. Dostęp 17 marca 2015.

Lairesse, Gerard de. The Art of Painting, in All Its Branches. Tłumaczenie John Frederick Fritsch. London: E. Orme, 1738.

Lairesse, Gerard de. The Great Book on Painting. Tłumaczenie Lyckle de Vries. W Lyckle de Vries, How to create beauty. De Lairesse on the theory and practice of making art, 1-36. Leiden: Primavera Press, 2011 (CD-ROM).

Lammerste, Friso, i Jaap van der Veen, red. Uylenburgh en zoon. Kunst en commercie van Rembrandt tot de Lairesse 1625-1675. Amsterdam: Waanders; Museum Het Rembrandthuis, 2006.

Lewicka-Morawska, Anna. Słownik malarzy polskich. Warszawa: Arkady, 1998.

Maciejczyk, Ewelina. „Zagadnienia techniki i technologii malarskiej Gerarda de Lairesse, XVIII wiek”. Praca magisterska, UMK w Toruniu, 2016.

Meijer, Fred G., i Adriaan van der Willigen. A Dictionary of Dutch and Flemish Still-Life Painters Working in Oils, 1525-1725. Leiden: Primavera Press, 2003.

Mosingiewicz, Anna, i Dariusz Kaczor. Portret ponad wszystko. Jacob Wessel i jego wiek. Sztuka Gdańska XVIII wieku. Gdańsk: Muzeum Narodowe, 2005.

Mosingiewicz, Anna, i Emanuel Okoń. „O obrazach, skrzynce cechowej i 'sztukach towarzyskich'. Uwagi o kształceniu artystycznym w Toruniu i Gdańsku na marginesie działalności Christiana Ernsta Ulricha, osiemnastowiecznego malarza w Toruniu”. Zapiski Historyczne 75 (2010) 1: 31-64.

Olszewska-Świetlik, Justyna. Gdański warsztat malarski schyłku XVII i XVIII wieku na przykładach wybranych portretów przedstawiających protestanckich duchownych. Toruń: Wydawnictwo Naukowe UMK, 2010.

Olszewska-Świetlik, Justyna, i Ewelina Pawlak. „Warsztat malarski cyklu obrazów emporowych z kościoła pod wezwaniem św. Jana w Gdańsku”. Acta Universitatis Nicolai Copernici. Zabytkoznawstwo i Konserwatorstwo 40 (2011): 195-222.

Pavey, Don. Colour Concepts Palettes and Pigments. London: Lulu Com, 2014. https:// books.google.pl/books?id=L4z8AwAAQBAJ\&pg=PA118\&dq=John+Fritsch+the+groot+schilderboek \&hl=pl\&sa=X\&ei=xOvdVIfLOuTmywOB3YIY \&ved=0CCEQ6AEwAA\#v=onepage \&q=John\%20Fritsch\%20the\%20groot\%20schilderboek\&f=false. Dostęp 6 marca 2016.

Roy, Alan. Gerard de Lairesse. Paris: Arthena, 1992. 
Schmidt-Degener, Frederik. "Le portrait de Gérard de Lairesse par Rembrandt". L'art flamand et hollandaise 19 (1913): 97-109. http://www.ncbi.nlm.nih.gov/pmc/articles/ PMC1079501/. Dostęp 15 marca 2015.

Schmidt-Degener, Frederik. "Rembrandt's Portret van Gérard de Lairesse”. Onze Kunst 23 (1913): 117-129. Dostęp 15 marca 2015, doi: 10.2307/3780829.

Snoep, Derk Persant. "Gerard de Lairesse als plafond- en kamerschilder”. Bulletin van het Rijksmuseum 18 (1970): 159-217. http://www.jstor.org/discover/10.2307/40381589?sid=21105671720833\&uid=2134\&uid=70\&uid=2 \&uid=38 7572221 \&uid=3\&uid=387572231\&uid=60. Dostęp 3 kwietnia 2014.

Ślesiński, Władysław. Techniki malarskie - spoiwa organiczne. Warszawa: Arkady, 1984. Van der Aa, Abraham Jacob. Biographisch woordenboek der Nederlanden. T. 7. Haarlem: BM Israel, 1862.http://www.dbnl.org/tekst/aa_001biog08_01/aa_001biog08_01_0481. php. Dostęp 4 marca 2016.

Van Rietschoten, Elsemieke, Monique Staal, Peter Eurlings, Indra Kneepkens, i Tatjana van Run. "Painting by the Rules of Art; the 'Groot Schilderboeck' Compared to the Painting Technique of Jan Lievens and Gerard de Lairesse”. Referat na International Symposium on Painting Techniques, Rijksmuseum, Amsterdam, 18-20 września 2013.

Vries, Lyckle de. Gerard de Lairesse. An Artist Between Stage and Studio. Amsterdam: Amsterdam University Press, 1998.

Vries, Lyckle de. How to Create Beauty. De Lairesse on the Theory and Practice of Making Art. Leiden: Primavera Press, 2011.

Weststeijn, Thijs. “The Visible World: Samuel van Hoogstraten's Art Theory and the Legitimation”. Simiolus. Netherlands Quarterly for the History of Art (15) (1985): 197-220. http://www.jstor.org/discover/10.2307/3780693?sid=21105713432483\&ui $\mathrm{d}=387572221$ \&uid $=60$ \&uid $=70$ \&uid $=3$ \&uid $=2$ \&uid $=387572231$ \&uid=2134. Dostęp 26 września 2014.

\section{Materiały internetowe}

AGRAART. http://www.agraart.pl/cgi-bin/autor.cgi?act=1 \&qt=1267736675\&nr=161. Dostęp 14 listopada 2015.

GENI. http://www.geni.com/people/Abraham-de-Lairesse/6000000027978901472. Dostęp 4 marca 2016.

MIKESTRAVELGUIDE.COM. http://mikestravelguide.com/things-to-do-in-amsterdam-visit-westerkerk-and-climb-westertoren/. Dostęp 14 listopada 2015.

RKD NETHERLANDS INSTITUTE FOR HISTORY. https://rkd.nl/en/artists/124717. Dostęp 4 marca 2016.

RKD NETHERLANDS INSTITUTE FOR HISTORY. https://rkd.nl/en/artists/82807. Dostęp 4 marca 2016. 
RKD NETHERLANDS INSTITUTE FOR HISTORY. https://rkd.nl/en/explore/artists/Lairesse\%2C\%20Johannes\%20de. Dostęp 4 marca 2016.

RKD NETHERLANDS INSTITUTE FOR HISTORY. https://rkd.nl/en/explore/artists/Webber\%2C\%20Zacharias\%20\%28II\%29. Dostęp 4 marca 2016.

Website DBNL vernieuwd. http://www.dbnl.org/tekst/houb005groo01_01/houb005groo01_01_0299.php. Dostęp 4 marca 2016.

Website DBNL vernieuwd. http://www.dbnl.org/tekst/houb005groo01_01/houb005groo01_01_0315.php. Dostęp 4 marca 2016.

Website DBNL vernieuwd. http://www.dbnl.org/tekst/houb005groo01_01/houb005groo01_01_0435.php. Dostęp 4 marca 2016.

Website DBNL vernieuwd. http://www.dbnl.org/tekst/houb005groo01_01/houb005groo01_01_0448.php. Dostęp 4 marca 2016.

WESTERKERK. http://www.westerkerk.nl/english. Dostęp 14 listopada 2015. 